\title{
A modernidade e a pós-modernidade servidas em dois jantares
}

\section{The modernity and the postmodernity served in two dinners}

Fernando Guilherme Tenório*

Não há, [...], nada de odioso no procedimento de um homem que, de boa-fé, pede provas da existência de um ser desconhecido que Ihe é anunciado. Todo o aspecto odioso estaria do lado dos partidários dessa existência se, como única resposta, ordenassem que o curioso fosse enviado para o suplício. (GIORDANO BRUNO) ${ }^{1}$

\section{Resumo}

Os conceitos de modernidade e pós-modernidade são discutidos em dois cenários gastronômicos, respectivamente nas cidades de Rio de Janeiro de final de século XIX e Recife em meados do século XX. O objetivo central da discussão é apontar a importância de ambos conceitos nos estudos organizacionais sob a perspectiva teórico-crítica.

Palavras-chave: Modernidade, modernização, moderno e pós-modernidade.

\section{Abstract}

The concepts of modernity and postmodernity are argued in two gastronomics situations, in the cities of Rio de Janeiro at the end of the XIX century and Recife in the middle of the XX century. The main objective of the argument is to center on the importance of both concepts in the organizational studies under the theoretical critical perspective.

Keywords: modernity, modernization, modern and postmodernity.

\section{Esclarecimento}

Os conceitos de modernidade e pós-modernidade têm sido, nos dois últimos séculos e no entrante XXI, um caminhar transversal ao pensamento ocidental tanto no que diz respeito a estudos que tratam de temas relacionados à estética, como nos debates envolvendo as ciências sociais. Tais alusões, em alguns casos, são utilizadas por puro modismo quando muitas vezes as pronunciamos sem saber, ao certo, do que estamos falando. Esses conceitos são apresentados como contraditórios, principalmente, porque pós-modernidade se distinguiria de modernidade pelo fato do prefixo pós (após), atribuir-lhe um conteúdo antitético a modernidade. No entanto, ainda não há consenso quanto a isso, haja vista as posições de Jean-François Lyotard e Jürgen Habermas, o primeiro defendendo a existência da pós-modernidade, o segundo sustentando a posição da modernidade ainda ser um projeto ${ }^{2}$.

Essa discordância pode estar assentada na seguinte pergunta: a inexorabilidade da modernidade continua nos dias de hoje ou o contemporâneo já é inspirado por outra categoria? Se considerarmos que a palavra moderno já existia "desde o século V da era cristã", 3 ou se consultarmos dicionários da língua portuguesa, encontraremos

\footnotetext{
- Doutor em Engenharia da Produção pela UFRJ. Mestre em Educação pela UFRJ. Bacharel em Administração pelo Instituto Metodista de Ensino. Professor da Escola Brasileira de Administração Pública e de Empresas da Fundação Getulio Vargas (EBAPE/FGV).Endereço: Praia de Botafogo, 190 - sala 507 - Botafogo - Rio de Janeiro//RJ. Brasil - CEP: 22250-900. E-mail. fernando.tenorio@fgv.br

${ }^{1}$ Du Marsais, 2008, p. 112.

2 "A modernidade: um projeto inacabado foi o título de um discurso que pronunciei em 1980 ao receber o prêmio Adorno" [da cidade de Frankfurt] (HABERMAS, 1989, p. 9).

3 "Segundo o seu uso à época do papa Gelásio I (494/5), o termo simplesmente faz a distinção entre os contemporâneos e o período anterior dos Padres da Igreja... Até hoje então a palavra latina modernus significa simplesmente 'agora'ou 'tempo do agora'..." (JAMESON, 2005, p. 27).
} 
que moderno identifica a época na qual uma pessoa vive e que a modernidade é a qualidade do que é moderno. Assim, por que discutir o seu oposto, a pós-modernidade se a modernidade está sempre em processo?

Apesar disso, a modernidade pode ser estudada como uma categoria datada na história da filosofia ocidental. Ela significaria uma época iniciada a partir da ruptura epistemológica com um passado em que o homem não tinha o direito de pensar, refletir sobre a sua condição de um ser para si. O seu cogito era subsumido por um pensar já dado, um saber originado numa luz que vinha do cimo, dos céus. $\mathrm{O}$ homem não poderia ter a sua própria luz, a consciência não se fazia por meio da experiência, mas do divino, do absoluto. Com a modernidade o secularismo se fez presente, a razão começava a se impor. Racionalidades começaram, então, a ser produzidas e a importância de ambos os conceitos para as ciências sociais tornaram-se fundamentais, em função do surgimento dos saberes especializados, que passaram a representar uma ruptura no conhecimento do homem e de suas ações diante dos outros e da natureza. ${ }^{4}$

Essa ruptura toma como referencia a substituição da epistemologia de base escolástica ${ }^{5}$ por outra para a qual converge o pensamento de autores como Francis Bacon (1561-1626), Hugo Grotius (1583-1645), Thomas Hobbes (1588-1679), René Descartes (1596-1650) e John Locke (1632-1704), que considera que toda certeza, toda verdade, deveria ser submetida a uma análise racional. Portanto, a modernidade parece ter sido iniciada no século XVI procurando libertar os indivíduos das crenças religiosas criando, assim, o homem moderno ${ }^{6}$. Porém a modernidade segue o seu propósito ilustrativo, esclarecedor, iluminando o século XVIII através da filosofia de Voltaire - François Marie Arouet (1694-1778), Jean-Jacques Rousseau (1712-1778), Denis Diderot (17131784), Immanuel Kant (1724-1804), ${ }^{7}$ Condorcet, marquês - Marie Jean Antoine Nicolas de Caritat (17431794), da Revolução Francesa (1789) e suas consequiências. ${ }^{8}$ Assim, os "termos ilustração, esclarecimento [Aufklärung], ${ }^{9}$ revolução francesa e modernidade constituem uma quatrinca, com as características sedutoras de uma sequiência cronológica": primeiro com "a pregação ilustrada", segundo com a "sua realização revolucionária" e terceiro com o "mundo moderno" 10 ou, quem sabe, de uma quina, por meio de uma "filosofia clandestina" $"$. No caso dos estudos organizacionais, a modernidade através do seu substantivo modernização, promove a racionalização do processo produtivo, pela incorporação da ciência e da técnica.

Por sua vez, a pós-modernidade seria uma categoria formulada nas primeiras décadas do Século XX significando uma mudança no pensamento estético e não como categoria de um determinado período. ${ }^{12}$ No

4 "Se o projeto da modernidade ficou - na hipótese de Habermas - ainda um projeto inconcluso, logo aberto e passível de diferenciações, então será uma alegre tarefa da memória rastrear no pensamento que se formou da Renascença às Luzes uma tradição 'moderna' de equilíbrio entre o Homem e a Natureza, indivíduo e sociedade" (itálico do autor, BOSI, 1992: 356).

5 "A escolástica caracteriza-se principalmente pela tentativa de conciliar os dogmas da fé cristã e as verdades reveladas pelas Sagradas Escrituras com as doutrinas filosóficas clássicas, destacando-se o platonismo e o aristotelismo", desenvolveu-se entre os séculos IX e XVII (JAPIASSU, 1990, p.84).

${ }^{6}$ Anthony Pagden diz que os "padrinhos da llustração são Epicteto, Cícero e Séneca" (PAGDEN, 2002, p. 77).

${ }^{7}$ Kant foi, provavelmente, o filósofo do Século das Luzes que melhor definiu a importância desta época ao contestar a "Resposta à pergunta: Que é 'Esclarecimento'? (Aufklãrung) [em 1783]. Esclarecimento [Aufklãrung] é a saída do homem de sua menoridade, da qual ele próprio é culpado. A menoridade é a incapacidade de fazer uso de seu entendimento sem a direção de outro indivíduo. 0 homem é o próprio culpado dessa menoridade se a causa dela não se encontra na falta de entendimento, mas na falta de decisão e coragem de servir-se de si mesmo sem a direção de outrem. Sapere aude! Tem coragem de fazer uso de teu próprio entendimento, tal é o lema do esclarecimento" (KANT, 2008, p. 63-64, grifos do autor).

${ }^{8}$ Os expoentes do lluminismo "acreditavam firmemente (e com razão) que a história humana era um avanço mais que um retrocesso ou um movimento oscilante ao redor de certo nível. Podiam observar que o conhecimento científico e o controle técnico do homem sobre a natureza aumentavam diariamente. Acreditavam que a sociedade humana e o homem individualmente podiam ser aperfeiçoados pela mesma aplicação da razão, e que estavam destinados a seu aperfeiçoamento na história. Com isto concordavam os liberais burgueses e os revolucionários proletários" (HOBSBAWM, 2004, p. 326).

9 “É impossível fazer uma tradução exata do termo filosófico alemão Aufklärung, tal a multiplicidade de sentidos congregados nesta noção. [Várias] tentativas foram feitas, nos diversos idiomas neolatinos [...] tais como 'iluminismo', 'ilustração', 'filosofia das luzes', 'época das luzes', etc. [...] Diversos motivos levam-nos a julgar que, sem ser perfeita, a transcrição da palavra 'esclarecimento' talvez seja de todas a melhor, principalmente porque acentua o aspecto essencial da Alfklärung, o de ser um processo e não uma condição ou uma corrente filosófica ou literária, [...] (KANT, 2008, p. 63).

${ }_{11}^{10}$ Rouanet, 1993, p. 159.

11 "Aquilo que chamamos de 'filosofia clandestina' constitui, sem dúvida nenhuma, uma das mais fascinantes páginas da história do pensamento e das idéias. O que se entende por isso é um amplo 'movimento' filosófico-literário, cuja marca foi a circulação (em geral secreta e anônima) de centenas de obras anticlericais e de crítica política no período compreendido entre os séculos XVI e XVIII. Tais obras (impressas ou manuscritas) refletiam a necessidade comum de expressar idéias pouco ortodoxas numa sociedade ainda refém da religião. Afinal, é preciso lembrar que a Inquisição ainda queimava seus 'hereges' e 'ímpios' em pleno século do lluminismo e da Revolução Francesa" (Du MARSAIS, 2008, p. 9).

12 "[O] termo pós-modernismo foi usado pela primeira vez por Federico de Onis, em 1934, numa antologia sobre poesia espanhola e hispano-americana, e desde que seu A Study of History Toynbee designou como época pós-moderna o período que se inicia em 1875, 
entanto, a partir dos anos 1970, o conceito passa a ser disseminado como característica de uma época variada, múltipla, determinada pelas diferenças. E o texto de concepção filosófica que vai procurar romper com as metas-narrativas modernas da dualidade de classes ou com o todo sistêmico, é A condição pós-moderna de Jean-François Lyotard ${ }^{13}$ obra segundo a qual "simplificando ao extremo, considera-se 'pós-moderna' a incredulidade em relação aos metarrelatos". ${ }^{14}$ No livro, Lyotard afirma que o "saber pós-moderno [...] aguça a nossa sensibilidade para as diferenças", ${ }^{15}$ ou a "tendência para o contrato temporário em todas as áreas da existência humana: a ocupacional, a emocional, a sexual, a política - laços mais econômicos, flexíveis e criativos que os da modernidade". ${ }^{16}$ Nesse sentido, a flexibilização organizacional e do trabalho caracterizariam uma gestão pós-moderna, pós-fordista, pós-industrial? ${ }^{17}$

Os argumentos com os quais se tentará corroborar essas posições categoriais - modernidade e pósmodernidade - serão apresentados a partir da descrição de dois jantares. Trata-se de regalórios inspirados naquela ceia narrada por Eça de Queiroz em seu romance $A$ cidade e as cerras. O primeiro deles, o ajantarado da modernidade, no qual foi servida uma garoupa de forno, "ocorreu" no final do século XIX, no Rio de Janeiro, na Rua do Ouvidor, no sobrado de número $192 .{ }^{18}$ Já o segundo repasto, que analisará a pósmodernidade, "aconteceu" em meados do século XX na cidade de Recife, mais especificamente no então Restaurante Buraco de Otília, Rua da Aurora 1231.

Os participantes dos dois jantares foram pessoas reais que fizeram parte da história das duas cidades, e tanto no ambiente carioca como no recifense, os comensais pertenciam a intelectualidade local. Cabe observar que recorrer a esses personagens reais numa situação fictícia, não teve como objetivo discorrer sobre suas biografias, mas, apenas, valendo-se de um artifício de redação, homenagear figuras da intelectualidade que contribuíram para a formação de um pensamento brasileiro.

Assim, a estrutura deste ensaio ${ }^{19}$ compreenderá, além deste I. Esclarecimento como introdução e da IV. Rua de Janus como conclusão, a narração do "acontecido" nos seguintes logradouros: II. Rua do Ouvidor, 192 local no qual os comensais discutirão a modernidade; e III. Rua da Aurora, 1231 quando o objeto da discussão será a pós-modernidade.

Cabe advertir que o presente ensaio não constitui um texto que explore o estado da arte e/ou que aponte todas as referências bibliográficas existente sobre os temas modernidade e pós-modernidade. O intento é tão somente versar sobre referências "que toca[m] o núcleo de pressupostos básicos que se encontram na raiz de nossas tentativas de compreender e lidar com o mundo e a maneira como o experimentamos" ${ }^{\text {20 }}$. Portanto, o objetivo não é esgotar o conhecimento já produzido a partir dessas rupturas epistemológicas em áreas como arte e a literatura, por exemplo, mas, tão somente, de forma lúdica, promover a aproximação entre esse conhecimento e

temos vivido sob o bombardeio de pós-moderno" (ROUANET, 1962, p. 87). O livro de Toynbee foi publicado no Brasil em 1986 pela Martins Fontes/Editora da UNB sob o título Um estudo da história.

13 Este livro foi publicado originalmente em 1979 em Paris pela Les Éditons de Minuit sob o título La condition postmoderne. No Brasil foi publicado pela primeira vez em 1986 pela José Olímpio, com o título O pós-moderno até a sua quarta edição quando, posteriormente, passou a ser denominado $A$ condição pós-moderna.

14 Lyotard, 2006, p. XVI.

15 Ibidem, p. XVII.

16 Anderson, 1999 , p. 33

17 Estas duas últimas acepções não serão aqui objeto de estudo. Desenvolvimento deste intento foi feito em Tenório, Fernando G. Flexibilização organizacional, mito ou realidade? Rio de Janeiro: Editora FGV, 2002, 2a. ed.

18 Este número é fictício embora, na realidade, "encontre-se" em um daqueles sobrados em direção ao Largo de São Francisco de Paula.

19 Sem nenhuma pretensão se aproximar-me sequer de Silvano Santiago, crítico literário e ensaísta, uso o seu argumento para tentar explicar as minhas intenções, ainda que pedestres, neste texto. Em entrevista concedida ao caderno Idéias do Jornal do Brasil, quando perguntado: - O sr. Costuma dizer que não escreve mais monografias acadêmicas e, sim, ensaios. Por quê? Responde Silvano Santiago: "- O ensaio se apresenta como um texto escorreito e de feição híbrida. Tem algo da escrita artística, acessível a todos alfabetizados, e algo da escrita científica, na sua plenitude só acessível aos especialistas. Por um lado, falta ao ensaio a total liberdade da arte, já que o ensaísta é um leitor que trabalha a partir de exemplos concretos, tomados não só a muitos livros e artigos, como aos vários meios de comunicação de massa. Por outro lado, faltam ao ensaio os princípios rígidos e disciplinares da ciência, já que o texto ensaístico traduz a obsessão de um indivíduo pelo conhecimento aberto e multidisciplinar de dada questão. O ensaio poderia servir de modelo para o diálogo entre o especialista e o não-especialista". Na pergunta seguinte - Foi o que procurou fazer em o Cosmopolitismo do pobre? (ver publicação), responde: - Paradoxalmente, na dupla insuficiência do ensaio - a falta de liberdade total e a pouco rígida cientificidade do ensaio - está sua redenção. [...] Dessa forma, o ensaio, à semelhança da arte, fala de maneira individual e firme (às vezes também ranzinza) sobre a atualidade. Por outro lado, por trabalhar uma linguagem conceitual, o ensaio, à semelhança da ciência, deve dialogar com todo e qualquer cidadão que se interessa pelas variadíssimas questões disciplinares propostas pela realidade nacional e internacional, tanto a histórica e sociológica, quanto a econômica e cultural” (SANTIAGO, 2005, p. 3).

${ }^{20}$ Johnson, 1997, p. 152. 
os estudos organizacionais. Assim, modernidade significará que "a verdade, a beleza e a moralidade existem como realidades objetivas que podem ser descobertas, conhecidas e compreendidas através de meios racionais e científicos"21; modernização será entendida como o processo de incorporação de tecnologias e dos conhecimentos necessários a suas implementações ${ }^{22}$; e pós-modernidade significará que "a verdade, [a] beleza e [a] moralidade não tem existência objetiva além do que pensamos, escrevemos e falamos sobre elas". ${ }^{23}$

Cabe apresentar o formato como serão apresentado os diálogos dos "personagens". Sempre em itálico, as falas serão, ora da lavra do autor, ora transcrições. Neste caso, ficarão entre aspas e uma nota de rodapé identificará a referência bibliográfica da citação. Também sempre em itálico aparecerão os termos objetos deste estudo: moderno, modernidade, modernização e pós-modernidade. Finalmente, convém comentar o possível número excessivo de citações, recorrendo a mais uma citação, destacada do O livro das citações: um breviário de ideias replicantes: "Não me inspiro nas citações; valho-me delas para corroborar o que digo e que não sei tão bem expressar, ou por insuficiência da língua ou por fraqueza do intelecto (Montaigne apud GIANNETTI, 2008, p. $15)$.

\section{Rua do Ouvidor, 192.}

A Rua do Ouvidor onde ocorreu o jantar da modernidade é uma das principais vias do centro do Rio de Janeiro contemporâneo como também o foi no final do século XIX: "a mais passeada e concorrida, e mais leviana, indiscreta, bisbilhoteira, esbanjadora, fútil, noveleira, poliglota e enciclopédica de todas as ruas da cidade do Rio de Janeiro, fala, ocupa-se de tudo". ${ }^{24}$

Desde que a cidade de São Sebastião do Rio de Janeiro teve a sua urbanização ampliada na segunda metade do século XVI com a descida de seus habitantes do "monte de São Januário (depois chamado de Castelo)" 25 para a planície, que este logradouro público faz parte da história desta cidade. A sua origem vai estar na então Rua Direita (hoje $1^{o}$. de Março) quando entre os anos 1568 e 1572 os moradores abriram um caminho em ângulo reto com a Direita, fato que lhe deu o primeiro nome, ainda não oficial, de desvio do mar. De 1590 a 1780 teve ainda as seguintes denominações em direção ao Largo São Francisco de Paula: Canto dos Meirinhos (à altura da Rua da Quitanda); Canto do Lucas do Couto, Rua do Gadelha, do Barbalho, da Santa Cruz, para finalmente Rua do Ouvidor. ${ }^{26}$ Apesar disso, entre 1897 e 1916, foi oficialmente denominada de Coronel Moreira César, nome que não vingou, impondo-se Rua do Ouvidor. ${ }^{27}$

Por ser a rua mais concorrida da cidade, a Ouvidor foi aquela na qual se inaugurou a iluminação a gás em substituição aos lampiões de azeite. Foi onde a modernidade se fez conhecer através de "um lundu ${ }^{28}$... composto (e logo se popularizou) para comentar musicalmente o acontecimento:

Estamos no século das luzes

\footnotetext{
${ }^{21}$ Johnson, 1997, p. 152.

22 Ibidem, p. 236.

${ }^{23}$ Ibidem, p. 152.

${ }^{24}$ Macedo, 1988, p. 7. A este propósito Ernesto Senna comenta: "Um escritor francês, Ferdinand Denis, que deixou um interessante livro sobre o Brasil, vinte anos depois da abertura dos portos [1808], comparou a nossa Rua do Ouvidor à Rue Vivienne em Paris, em que os armazéns de modas, os armarinhos e as modistas se acumulavam, ostentando soberbas vidraças de amostras" (SENNA, 2006, p. 24). Parece ser que há uma outra versão sobre esta percepção francesa da Rua do Ouvidor: "Dela dizia, nas suas impressões sobre o Brasil, o naturalista e escritor francês Victor Jacquemont: 'No Rio... a Rua Vivienne da terra, que aqui se chama do Ouvidor, está apinhada de modistras, alfaiates e penteadores de Paris... E assim é que no Rio de Janeiro, graças a uma regra sumariamente falsa, pensa todo o mundo que todos os franceses são cabeleireiros e todas as francesas prostitutas..." (GERSON, 1965, p. 64).

${ }^{25}$ Macedo, 1988, p. 7.

${ }^{26}$ O nome Rua do Ouvidor foi oficializado em 1780 em homenagem ao ouvidor da comarca do Rio de Janeiro, Dr. Francisco Berquó da Silveira que "logo ou depois de sua chegada à capital do Brasil colônia [vindo de Lisboa] foi morar na então Rua do Padre Homem da Costa" (MACEDO, 1988, p. 40).

27 "A propósito, vale a pena recordar-se aqui o episódio vivido por Artur Neiva numa de suas viagens. Conversava ele com um australiano sobre o Brasil, e como este se queixasse da diferença tremenda entre o falar-se e o escrever-se a nossa língua, disse-lhe: - Cite-me então um exemplo disso, pois me parece que o senhor exagera... - Pois no Rio de Janeiro o nome da rua principal, escrito nas placas, é Moreira César: aqui está nos meus apontamentos. Mas para todos os brasileiros a sua pronúncia é Rua do Ouvidor" (GERSON, 1965, p. 64).

${ }^{28}$ Lundu dança de par separado, de origem africana, em compasso binário com primeiro tempo sincopado; mulundu [Trazida pelos escravos bantos, com meneios e requebros de forte apelo sensual, manteve esse caráter jocoso e tornou-se dança de salão muito em voga no Brasil do sXVIII ao início do sXX.] DICIONÁRIO ELETRÔNICO HOUAISS DA LíNGUA PORTUGUESA.
} 
Não podemos duvidar

Anda gás por toda parte

Para nos alumiar. ${ }^{29}$

O esclarecimento, do início do Século XIX aquele do Século XX, igualmente se fez presente na Rua do Ouvidor através da imprensa escrita: Jornal do Comércio, A Nação, Diário de Notícias, O País, Gazeta de Notícias, O Binóculo, Correio da Manhã, A Notícia, A Reforma, Folha Popular, A Imprensa, A República, Semana Esportiva, Revista da Semana, O Malho, Rua do Ouvidor, A Ordem, Rio-Jornal, A Batalha, A Esquerda e O Esporte. Da mesma forma, a modernização industrial se fez notar com a instalação "dos primeiro elevadores (ou o primeiro) chegados ao Brasil" na então famosa joalheria Mappin \& Webb. Na busca pela modernização para o lar, em meados do Século XIX "donas de casa as dezenas a ela ocorreram, cheias de curiosidade, para ver de perto as primeiras máquinas de costura trazidas ao Brasil pela Singer" ${ }^{30}$ Foi também na Ouvidor, que o moderno se fez presente quando na loja Ao Rei dos Mágicos, Antônio Ribeiro Chaves criou o telefone no Brasil. Chaves tinha vocação para inventor, e lendo numa revista francesa a descrição do aparelho experimentado na Exposição de Filadélfia pelo próprio Pedro II, a ela presente, cismou de fabricá-lo sozinho, com os recursos encontrados à mão na cidade. ${ }^{31}$ A Rua do Ouvidor era tão iluminada $\mathrm{e}$

Tão decisiva [...] sua influência na vida da cidade que no dia seguinte [a proclamação da República] escreveu o 'Diário de Notícias': 'Deodoro não temera a metralhadora do Quartel General nem o revólver do Barão de Ladário, mas temia a passagem pela Rua do Ouvidor, desfiladeiro do nosso espírito, rua legendária da liberdade, nosso Fórum, nosso Monte Aventino, onde o povo diariamente se reúne e delibera.' Pelo seu iluminismo vale também a pena lembrar que nela foi aberta a sede do Clube da Reforma, fundado em 1868, com propósitos de renovação política [...]. ${ }^{32}$

A Rua do Ouvidor "não era apenas a mais mundana, jornalística e política das nossas ruas". A ilustração também se fazia presente através de "suas livrarias-editoras, como a Laemmert, a Garnier e a Francisco Alves." Ali a modernização se fez presente por meio do cinema primitivo na última década do Novecentismo (o "kinetoscópio" ou o "animatógrafo") [...] os emissários de Edison [trouxeram para suas lojas] os primeiros fonógrafos de sua invenção... e a repetirem discursos e músicas que 'inexplicavelmente eram enlatados, como se não tivessem vida', [...]".

E a "abertura da Avenida Rio Branco, nos primeiros anos [do Século XX], veio destroná-la pouco a pouco dessa sua condição de [moderna, onde] a tarde, das três as cinco, [desfilava] a elegância e o espírito". ${ }^{33}$ A Rua do Ouvidor no final do século XIX perturbava os personagens machadianos como foi o caso de Mariana que ao acompanhar a sua amiga Sofia

sentiu-se um pouco atordoada, como sempre lhe acontecia. A uniformidade e a placidez, que eram o fundo do seu caráter e da sua vida, receberam daquela agitação os repelões de costume. Ela mal podia andar por entre os grupos, menos ainda sabia onde fixasse os olhos, tal era a confusão das gentes, tal era a variedades das lojas. [...] - Esta Rua do Ouvidor! $!^{34}$

O sobrado onde o jantar da garoupa assada vai promover o debate sobre a modernidade, era uma casa de três pavimentos, localizada nos finais da rua ilustrada. $\mathrm{O}$ andar térreo era destinado aos serviços, no segundo andar encontrava-se o bureau, a biblioteca, a sala de estar e uma de jantar, e no terceiro ficavam dois amplos quartos e casa de banho com duches importadas de Paris. O sobrado era apetrechado com os mais novadios equipamentos então existentes: telégrafo, 35 telefone 36 e outros engenhos da época37. O dono de tão moderna

\footnotetext{
${ }^{29}$ Gerson, 1965, p. 66.

${ }^{30}$ lbidem, p. 66 .

${ }^{31}$ Ibidem, p. 68 -71.

32 Ibidem, p. 72-73.

${ }^{33}$ Ibidem, p. 74-75.

${ }^{34}$ Assis, 2008, p. 103.

35 "Na segunda metade do século XIX, a cidade ganha um sistema de comunicação telegráfica para a Europa (1850)" (GARCIA, 2000, p. 47).
} 
residência era Aluísio Neto, filho de rico comerciante português de secos e molhados e que herdara quintas em Portugal, terras no Brasil, além de negócios e imóveis na cidade e no além mar. Afora de ser um homem de posses, era dado a leituras, licenciado que fora em Paris. Não podemos esquecer que neste final de Século XIX o Rio de Janeiro como capital do país, já possuía eletricidade. O progresso, a modernização de acordo com as tecnologias da época, já fazia parte da realidade brasileira, pelo menos na nossa cidade luz.

O sobrado da nossa estória no mesmo logradouro da Livraria Garnier "conhecida entre a estudantada da época" como o Bom Ladrão Garnier, ${ }^{38}$ da Casa Clark - do calçado "Único e superior no Brazil", do "Impermeável, cômodo, elegante e sólido". ${ }^{39}$ Nele, os convivas poderiam deparar-se com todo o progresso e conforto que a civilização podia oferecer. Aluísio Neto já instalara um pequeno elevador para transportar os alimentos do andar térreo ao segundo e terceiro pavimento. Do primeiro ao terceiro piso, a casa era ligada por uma escadaria de madeira nobre, jacarandá, vinda do Norte, das terras do nosso anfitrião.

Antes de partir em férias para Paris, onde passaria o réveillon da virada para o Século XX com os amigos da capital francesa, Aluísio Neto resolveu convidar achegados para uma despedida temporária, alguns já não freqüentavam o sobrado há tempos, desconhecendo, portanto, os apetrechos modernos que ali tinham sido instalados. Ficaram espantados: "toda uma mecânica sumptuosa, aparelhos, lâminas, rodas, tubos, engrenagens, hastes, friezas, rigidezas de metais." ${ }^{40}$ Tal espanto, leva um dos admiradores a fazer a seguinte observação: "acumulaste civilização Aluísio, Santo Deus! [...] Está tremendo, o 192!"” ${ }^{11}$ Ao que ele respondeu: "Sim, há confortos ... Mas falta muito! A humanidade ainda está mal apetrechada, [...] a vida conserva resistências", ${ }^{42}$ contradições não resolvidas, injustiças. Quem fala de injustiças? - retruca João Menezes - Tu, Aluísio?! Um burguês, um industrial revolucionário. Neste momento de enlevo iluminista, enquanto o anfitrião segurando mais um artefato pronunciava a educada frase Com quem tenho a honra de falar?, os convidados percebem que ele estava usando de mais um instrumento moderno, o telefone, que está sobre o birô ao lado de "uma estranha e miúda legião de instrumentozinhos de níquel, de aço, de cobre, de ferro, com gumes, com argolas, com tenazes, com ganchos, com dentes, expressivos todos, de utilidades misteriosas." ${ }^{43}$

Aproveitando este interregno telefônico um curioso conviva, Azevedo Lima, tenta manejar um daqueles instrumentozinhos e "logo uma ponta malévola" [lhe fura] "um dedo. E neste instante rompeu de outro canto um tique-tique açodado, quase ansioso". ${ }^{4}$ Aluísio apontou para o conviva bisbilhoteiro: "Vê aí o telégrafo! [...] Ao [lado] do divã. Uma tira de papel que deve estar a correr. E, com efeito, duma redoma de vidro posta numa coluna, e contendo uma aparelho esperto e diligente, escorria para o tapete, como uma tênia, a longa tira de papel com caracteres impressos". ${ }^{45}$ Azevedo Lima ficou perplexo, e contemplando o espaço de trabalho de nosso anfitrião, observou uma máquina de escrever, outra de calcular, arames que luziam e "que fugiam através do tecto para o espaço". ${ }^{46}$

O amigo perplexo continuou a sua parcial incursão pela casa civilizada, deparando-se a cada instante com novidades. Por exemplo, uma biblioteca vastíssima com livros que tratavam de todo tipo de assunto discutido pelo mundo intelectual até então, principalmente, textos do Século XVI ao XIX, ao ponto de perceber, "espantado, oito metros de" ${ }^{47}$ Iluminismo: Voltaire, Rousseau, Diderot, Kant, Condorcet, Hegel, Marx... Contudo surpresa maior teve o amigo ao ouvir uma voz: "E assim, pela disposição dos cubos diabólicos, eu

\footnotetext{
${ }^{36}$ O telefone já era realidade no Rio de Janeiro "desde o início dos anos 80" do século XIX alcançando em 1889 "10 mil assinantes [...] O telefone tinha se transformado num requinte com 0 ar meio francês do centro da cidade, acessório chique dos cafés, luxo para almofadinhas e beldades [...]" (TELERJ, 1994, p. 38).

37 “[...], para tentar identificar os timbres e ritmos peculiares da modernidade do século XIX, a primeira coisa que observaremos será a nova paisagem, altamente desenvolvida, diferenciada e dinâmica, na qual tem lugar a experiência moderna. Trata-se de uma paisagem de engenhos a vapor, fábricas automatizadas, ferrovias, amplas zonas industriais; prolíficas cidades que cresceram do dia para a noite, quase sempre com aterradoras conseqüências para o ser humano; jornais diários, telégrafos, telefones e outros instrumentos de media, que se comunicam em escala cada vez maior; [...]" (BERMAN, 1986, p. 18).

${ }^{38}$ Fundada por Batista Luiz Garnier e filial a de Paris (SENNA, 2006, p. 45)

${ }^{39}$ Senna, 2006, p. 230.

${ }^{40}$ Queiroz, 1925, Vol. I: p. 360.

41 lbidem, p. 361.

42 Ibidem, p. 361.

${ }^{43}$ Ibidem, p. 361.

44 Ibidem, p. 361.

${ }^{45}$ Ibidem, p. 361.

${ }^{46}$ Ibidem, p. 362.

${ }^{47}$ Ibidem, p. 362.
} 
chego a verificar os espaços hipermágicos!"48 Com o susto gritou aos quatro cantos: "Aluísio, aqui há um homem! Está aqui um homem a falar dentro duma caixa!" "Imediatamente o civilizado Aluísio responde: "É $o$ conferençofone [...] Exatamente como o teatrofone; somente aplicado às escolas e às conferências. Muito cômodo!" 50

Então Azevedo perguntou para Aluísio: "para que servem todos estes instrumentozinhos? Houve já aí um desavergonhado que me picou. Parecem perversos [...] são úteis?" ${ }^{51}$ Ao que este respondeu com um gesto que os sublimava: "Providenciais meu filho, absolutamente providenciais pela simplificação que dão ao trabalho!" 52 modernizam as nossas tarefas. Eficientes. E apontou, "este arrancava as penas velhas; o outro numerava rapidamente as páginas dum manuscrito; aqueloutro, além, raspava emendas [...] E ainda os havia para colar estampilhas, imprimir datas, derreter lacres, cintar documentos [...] Mas, com efeito, acrescentou, é uma [desconformidade]. Com as molas, com os bicos, às vezes magoam, ferem... Já me sucedeu inutilizar cartas por as ter sujado com dedadas de sangue. É uma maçada!" 53 Ser moderno, comenta Aluísio, "é viver uma vida de paradoxo e contradições". ${ }^{54}$

Apesar de toda aquela modernização, Aluísio Neto tinha as suas precauções. Possuía um móvel, um aparador, que armazenava quantidade assustadora "de águas - águas oxigenadas, águas carbonatadas, águas fosfatadas, águas esterilizadas, águas de sais, outras ainda" $"$. Descoberta que fez o curioso João Menezes vindo de outra sala perguntar: "Santíssimo nome de Deus, Aluísio! Então és ainda o mesmo tremendo bebedor de água, hem? Um acuático!" "56 Ao que Aluísio respondeu: "Não. É por causa das águas [desta] cidade, contaminadas, atualhadas de micróbios... Mas ainda não encontrei uma boa água que me convenha, que me satisfaça... Até sofro sede". 57

Voltemos ao relato principal, o jantar. A matéria-prima do prato principal, do prato de resistência, foi ofertado por um dos amigos de nosso anfitrião, Emílio Barreto, intelectual que era também dado a dotes culinários e conhecedor dos peixes da costa brasileira que, no dia do jantar, logo de manhã cedo, comprara no mercado de peixe ao lado da Praça XV uma bonita e grande garoupa, não de mentirinha, de verdade, um bom peixe para assar disse Emílio. "Eu queria um almoço curto" pondera Aluísio, adicionando: o João Menezes "queria uma ceia. É um bárbaro, besuntado com literatura do século XVIII, que ainda acredita em ceias" ${ }^{58}$, em liberdade ,em igualdade e em fraternidade, os lemas da Revolução Francesa em 1789.

O jantar começa a ter seus problemas civilizatórios com a falta de luz no 192. Fato que obrigou a busca dos "candelabros abandonados, os pesados castiçais arcaicos dos tempos incientíficos, [pré-modernos]: era uma reserva de veteranos fortes, para o caso pavoroso em que mais tarde, à ceia, falhassem perfidamente as forças bisonhas da civilização". ${ }^{9}$

O jantar começou a ser servido. De entrada um consommé frio para, em seguida, o prato principal, a garoupa que seria acompanhada de um autêntico Alvarinho. E eis que entra o mordomo, "reluzente de suor, e balbuciou uma confidência [ao Aluísio] que mordeu o beiço, traspassado." ${ }^{60}$ Emílio emudecera sobre uma história de pescaria que contava. "Todos se entreolhavam, numa ansiedade alegre." paciência, com heroicidade, forçando palidamente o sorriso", [anuncia]: Meus amigos, há uma desgraça". ${ }^{62} \mathrm{E}$ um dos convivas pergunta: "Fogo? Não, não era fogo. Fora o elevador dos pratos que inesperadamente, ao subir [a garoupa], se desarranjara, e não se movia, encalhado! ${ }^{63}$ A reação de Emílio foi de ira: "Essa é forte!

\footnotetext{
${ }^{48}$ Ibidem, p. 363.

49 lbidem, p. 363.

${ }^{50}$ lbidem, p. 363.

${ }^{51}$ lbidem, p. 364.

52 Ibidem, p. 364.

53 lbidem, p. 364.

${ }^{54}$ Berman, 1986, p.13.

${ }^{55}$ Queiroz, 1925, Vol. I, p. 365.

${ }^{56}$ lbidem, p. 365.

${ }^{57}$ Ibidem, p. 365.

58 lbidem, p. 378.

${ }^{59}$ lbidem, p. 379.

60 Ibidem, p. 388.

${ }^{61}$ Ibidem, p. 388.

62 Ibidem, p. 388.

63 lbidem, p. 388.
} 
[...] Pois um peixe que meu deu tanto trabalho! Para que estamos nós aqui então a cear? Que estupidez! E por que o não trouxeram à mão, simplesmente? Encalhado [...] Quero ver! Onde é a copa?"64

Chegando à copa Emílio precipitou-se no poço escuro do elevador onde "sobre uma larga prancha, o peixe precioso alvejava, deitado na travessa, ainda fumegando, entre rodelas de limão." vão para fazer com que o elevador voltasse a funcionar. Até a idéia de pescar o peixe foi sugerida. Com uma bengala, um cordel e um grampo de cabelos de uma das convidadas, Maria Quitéria redatora das mundanidades cariocas. Emílio intentou uma nova pescaria da garoupa. Debalde. Emílio vociferava "Oh Aluísio, erga essa luz! - inchado e suado - [...] Mais! [...] Agora! Agora! É na guelra! Só na guelra é que o gancho o pode prender. Agora [...] Qual! Que diabo! Não vai!" 66 Todos desistiram da pescaria no poço do elevador, na copa do 192, e voltaram para a sala de jantar sôfregos da pescaria. "Ser moderno, [comenta Rodrigo Lopes já famélico], é estar aberto às possibilidades que as aventuras da modernidade nos conduzem. [Continuou Rodrigo]: para ser inteiramente moderno é preciso ser anti-moderno: desde os tempos de Marx e Dostoievski até o nosso próprio tempo, tem sido impossível agarrar e envolver as potencialidades do mundo moderno sem abominação e luta contra algumas das suas realidades mais palpáveis", ${ }^{67}$ prosseguindo, conclui: a realidade é que tenho fome, por quê não encomendamos um pernil na Confeitaria Paschoal $?^{68}$ Fica logo ali no 128. E assim foi feito, encomendou-se um pernil com batatas.

$\mathrm{Na}$ espera e sobressaltados "pelo abismo niilista ao qual tantas das aventuras modernas conduzem"69, os convidados iniciaram um debate em torno do significado do moderno, ou da modernidade diz João Menezes, não seria modernização argüi Azevedo Lima. Como vocês estão sob os meus domínios, vocifera Aluísio, devem aceitar que a modernidade já têm dois séculos, é bicentenária. Ao que complementa Emílio Barreto: pode ser até mais se consideras os descobrimentos marítimos, mas vê-se que ela chegou a tua casa amigo Aluísio, apetrechos e mais apetrechos, pois, a "modernidade sempre teve algo a ver com a tecnologia [...] $e$, dessa forma, em última análise, com o progresso", ${ }^{70}$ com a ordem. Vejam o lema da nossa bandeira - ordem e progresso.

Maria Quitéria pergunta: oh Aluísio o que vás tu fazer em Paris, na Cidade Luz aonde nasceu o Iluminismo? Enfadado com o acontecido, Aluísio responde: "vou a busca de mais novidades, uma delas é sobre como conduzir melhor os meus negócios que precisam modernizar-se. Escreveu-me o nosso confrade Francisco d'Izaque. Dizia na carta que comandar os negócios exige conhecimento, algumas idéias já existem a respeito. Mas antes de Paris passo por Nova York onde já se fala muito sobre o tema. ${ }^{71}$ No que é complementado por João Menezes és um burguês, realmente um burguês Aluísio, tens cuidado porque a "economia capitalista moderna é um imenso cosmos no qual o indivíduo nasce, e que se lhe afigura, ao menos como indivíduo, como uma ordem de coisas inalterável, na qual ele tem de viver. Ela força o indivíduo, à medida que esse esteja envolvido no sistema de relações de mercado, a se comportar com as regras do comportamento capitalistas. $O$ fabricante que se opuser por longo tempo a essas normas será inevitavelmente eliminado do cenário econômico, tanto quanto um trabalhador que não possa ou não queira se adaptar às regras, que será jogado na rua, sem emprego". ${ }^{72}$

\footnotetext{
${ }^{64}$ Ibidem, p. 388.

65 Ibidem, p. 388.

${ }^{66}$ Ibidem, p. 389.

${ }^{67}$ Berman, 1986, p. 6

${ }^{68}$ Senna, 2006, p. 59.

${ }^{69}$ Berman, op. cit., p. 14.

70 Jamenson, 2005, p. 16

${ }^{71}$ No final de Século XIX e início do XX, a modernização dos processos produtivos através do gerenciamento já se fazia presente nos trabalhos de Josua Rose (engenheiro inglês, consultor em Nova York, que em 1876 publicou o artigo "Modern machine shop practice" na Scientific American) e possivelmente era do conhecimento de Frederick W. Taylor [1856-1915], (Kanigel, 1997). Deve-se considerar também que em 1880 foi criada a American Society of Mechanical Engineers, corporação de profissionais que estimulou a gestão de empresas por métodos científicos (HARMON; MAYER 1999). Deve ser igualmente levado em conta que em 1881 foi inaugurada na Universidade da Pensilvânia, a Wharton School, a primeira instituição de ensino superior em Administração do mundo. Em 1903, Taylor publicou Shop management, pela Harper \& Bros., de Nova York. Anteriormente, o Imperador D. Pedro II sancionara a Lei n. 556 , de 25 de junho de 1850, que em seu artigo 35 criava a profissão de administrador (VIANNA, 2006).

72 Weber, 2001, p. 48.
} 
Em síntese, diz o engenheiro, o capitalismo "veio para dominar a vida econômica, educa e seleciona os sujeitos de quem precisa, mediante o processo de sobrevivência econômica do mais apto" "73 e "um tipo de Iluminismo liberal parece ser a base mais adequada para o sucesso de tal homem de negócios". ${ }^{4}$

Após a fala do João Menezes, os presentes se entreolharam e Maria Quitéria a única mulher no recinto, disse: Digno de um artigo para o meu jornal. Bravo! Bravíssimo! Isto é puro "racionalismo econômico". 75 "Sem dúvida, [contesta o engenheiro], se entendermos por isso a extensão da produtividade do trabalho que aliviou, mediante a subordinação dos processos produtivos aos pontos de vista científicos, sua dependência das limitações naturais orgânicas do ser humano. Atualmente, esse processo de racionalização no campo da organização econômica e técnica, sem dúvida determina uma boa parte das idéias de vida da sociedade burguesa moderna"76 na qual Aluísio e nós estamos começando a nos inserir. E mais, continuou João Menezes, "o desenvolvimento do espírito capitalista seria melhor compreendido como sendo parte do desenvolvimento do racionalismo como um todo, e poderia ser deduzido das posições fundamentais do racionalismo sobre os problemas básico da vida". ${ }^{77}$

Calma! Calma! - prossegue João Menezes - estas idéias não são minhas, são do sociólogo alemão Max Weber que descreve este processo de racionalização como um processo que desencantou o mundo, notadamente o nosso mundo ocidental, a partir do final do Século XVIII e que passa a substituir a cultura religiosa pela leiga. Porém ele, Max Weber, diz que tal mudança não só ocorre na "profanação da cultura ocidental mas, sobretudo na evolução das sociedades modernas. As novas estruturas sociais vem determinadas pela diferenciação desses sistemas funcionalmente [inter-atuantes] que se cristalizam ao redor dos núcleos organizativos que são a empresa capitalista e o aparato burocrático estatal. Este processo entende Weber como a institucionalização da ação econômica com respeito a fins." ${ }^{, 18}$ E, a modernização é um "processo acumulativo e que se reforça mutuamente através da formação do capital e da mobilização de recursos, do desenvolvimento das forças produtivas e do incremento da produtividade e do trabalho."79

Já tarde da noite, depois de degustado o pernil com batatas douradas da Confeitaria Paschoal acompanhado que foi não de Alvarinhos mas de tintos originados do Dão, quando todos se recolhiam as suas casas, Emílio ainda argüiu: "O peixe Aluísio, desencalha o peixe! Excelente, ao almoço, frio, com um molho verde!" Menezes para não deixar o dono da casa triste comenta: "Foi divertido, Aluísio! [...] Grande pena o elevador" ${ }^{81}$ O que nos prega a modernidade. Sempre com as suas contradições. Junto à modernidade, a solução, vem o problema. E Aluísio num som cavo que era bocejo e rugido ao mesmo tempo, acrescenta: "Uma maçada! E tudo falha!" 82 No que é acraticamente aparteado por João Menezes: "hoje a única emoção, verdadeiramente fina, seria aniquilar a civilização. Nem a ciência, nem as artes, nem o dinheiro, nem o amor, podiam já dar um gosto intenso e real às nossas almas saciadas. Todo o prazer que se extraíra de criar, estava esgotado. Só restava, agora, o divino prazer de destruir." ${ }^{\text {"3 }}$

\section{Rua da Aurora, 1231.}

Apesar do momento recriado nesta narrativa tratar-se de meados do século passado, a divulgação do conceito de pós-modernidade só ocorre intensivamente no final da década de 1970, disseminado pela obra de Lyotard, $A$ condição pós-moderna. No entanto, recorrendo ao argumento do próprio Lyotard a "hipótese de trabalho é a de que o saber, muda de estatuto ao mesmo tempo que as sociedades entram na idade dita pós-industrial e as culturas na idade dita pós-moderna. Esta passagem começou desde pelo menos o final dos anos 50 " ${ }^{84}$ Não

\footnotetext{
${ }^{73}$ Ibidem, p. 48.

${ }^{74}$ Ibidem, p. 58.

${ }^{75}$ Ibidem, p. 62.

${ }^{76}$ Ibidem, p. 62.

77 Ibidem, p. 62.

${ }^{78}$ Habermas, 1989 , p. 11-12.

79 lbidem, p. 12.

${ }^{80}$ Queiroz, 1925, Vol. I, p. 390.

81 lbidem, p. 390.

82 Ibidem, p. 390.

83 Ibidem, Vol. I, p. 387.

${ }^{84}$ Lyotard, 2006, p. 5. Por sua vez, o Dicionário de Teoría Crítica y estúdios culturales diz que "o pós-modernismo designa certo número de manifestações nas artes e cultura da segunda metade do século XX. [...] Em segundo lugar, aludi a emergência de novas formas de
} 
queremos com isto dizer que a Recife do final dos anos 50 já estivesse na era pós-industrial, porém "antecipar um debate", uma vez que a intelectualidade pernambucana possuía conteúdo para tal, possibilidade que será observada mais adiante.

A modernidade e a modernização já estavam presentes na cidade de Recife desde o século XIX, com o surgimento da Escola de Recife como corrente filosófica ${ }^{85}$, mas "sobretudo, [pelas] novidades de que a cidade era pioneira [...]. [Na capital pernambucana] correu a segunda locomotiva a vapor chegada ao Brasil, [que] veio equipar a Estrada de Ferro Recife-São Francisco, em 1858". ${ }^{86}$ Dada a sua proximidade geográfica com a Europa, a modernização foi vista pelos recifenses de então por meio de Gago Coutinho e Sacadura Cabral, que realizaram "a primeira travessia por avião do Atlântico Sul" ${ }^{87} \mathrm{em} 1922$ e pela passagem do Graf Zepelin, em 1930, a caminho do Rio de Janeiro. ${ }^{88}$ Além disso, dos "anos 20 ao início da década de 30 [Recife] desenvolveu uma intensa atividade na área do cinema [...], movimento que alguns chamam de Cinema Pernambucano [e que] é na verdade mais próprio chamar de Ciclo do Recife [...], uma das primeiras manifestações cinematográficas no Brasil [...]". Na ocasião, além de documentários, curtas e longas-metragens, "fez-se também o primeiro filme publicitário no país, Um ato de humanidade, que promovia um remédio popular, uma 'garrafada ${ }^{89}$ sertaneja!"’90 Nas artes cênicas, o Teatro de Amadores de Pernambuco é o grupo mais antigo do país, desde abril de $1941 .^{91}$ Nas décadas iniciais do século XX, outras instituições voltadas à modernidade faziam parte do cenário recifense: Academia Pernambucana de Letras, o Cenáculo Pernambucano de Letras, o Silogeu Pernambucano de Letras, o Grêmio Recifense de Letras, o cenáculo da Livraria Silveira e Sociedade de Arte Moderna do Recife. ${ }^{92}$

Falemos, então, da Rua da Aurora, construída na área de um alagado aterrado, o Pântano do Casimiro. O proprietário da área, Casimiro Antônio de Medeiros, aproveitou o espaço para construir casas que fossem banhadas pelos raios de sol da manhã, daí a popularização do nome Rua da Aurora. ${ }^{93}$ "Tinha início, desta forma, o primeiro trecho do novo arruamento, margeando o Rio Capibaribe, partindo da ponte e do aterro da Boa Vista", ${ }^{94}$ terminando entre a Ponte do Limoeiro e a Avenida Norte. Além de sua beleza por margear o rio Capibaribe, a Rua da Aurora é o local onde foram construídos prédios que contribuíram, e ainda contribuem, para a história urbana da capital pernambucana. São exemplos dessas construções, além de casarões e palacetes, a Fábrica da Fundição d'Aurora, Clube Internacional, um templo maçônico, Senado Estadual, antiga residência do Conde da Boa Vista, Ginásio Pernambucano, Assembléia Legislativa, Clube Esportivo Almirante Barroso ${ }^{95}$. "Durante o 'tempo dos bondes' ela era servida por uma linha com seu nome, em toda a sua extensão, até à Rua do Lima, onde terminava". ${ }^{96}$

É também na Rua da Aurora que vai surgir, em 1946, o Buraco de Otília nome originado da sua primeira proprietária, Otília Pereira da Silva. Construído inicialmente sobre palafita nas águas do Capibaribe foi transferido, em 1956, quando da urbanização do Cais da Rua Aurora para o n. 1231 da mesma rua. ${ }^{97}$ O que tinha o Buraco de Otília que os outros não tinham? A resposta é dada pela qualidade e originalidade da comida que ali era servida. Diz-se que durante os seus tempos áureos, final dos anos 40 e meados dos 50, até um

organização social e econômica, grosso modo [grifo do original] desde a guerra de 1939-1945. [...] Em terceiro lugar, assinala um tipo particular de escritura e reflexões teóricas, geralmente, ainda que não exclusivamente, escritura e reflexão que tomam a primeira ou a segunda área como objeto. Pode ser útil distinguir estas três áreas de aplicação com os termos pós-modernismo, pós-modernidade e o pós-moderno" (PAYNE, 2002, p. 528, grifos do original).

${ }^{85}$ Paim, 1981, p. 1.

${ }^{86}$ Menezes, 2004, p. 21.

87 Ibidem, p. 21.

${ }^{88}$ Ibidem, p. 21.

89 "1. Xarope caseiro, feito de ervas medicinais para purificar o sangue ou curar alguma doença" (BERNARDINO, 2002, p. 106).

${ }^{90}$ Menezes, 2004, p. 32-33.

91 Ibidem, p. 45.

${ }^{92}$ Carpeggiani, 2004, p. 1.

${ }^{93}$ Além da Rua da Aurora, outras ruas foram criadas neste antigo alagado: Imperatriz, Conde da Boa Vista, Riachuelo, Princesa Isabel, Saudade e União (BRAGA, 2002).

${ }_{94}^{4}$ Cavalcanti, 2002, p. 56.

95 Dedicado a prática do remo (BRAGA, 2002, p. 116).

${ }^{96}$ Cavalcanti, 2002, p. 58.

${ }^{97}$ Com a morte de Otília em 1976, sua filha Rosângela Pereira da Silva assume o estabelecimento. "O restaurante [funcionou] na mesma Rua da Aurora, [...] não mais no casebre [palafita] demolido na primeira gestão do Prefeito Augusto Lucena, porém numa casa que já [fora] residência do Espanhol, onde, conforme se diz, Otília trabalhava como serviçal" (CAVALCANTI, 1999, p. 61). "[Desde] a época em que se instalava na maré da beira do rio, [o restaurante] exibe nas suas paredes retratos das figuras importantes da nossa República que tiveram a oportunidade de deliciar-se com a sua culinária" (BRAGA, 2002, p. 116). 
presidente da república provou dos quitutes elaborados por Otília. O seu cardápio era dividido em oito seções: aves (da qual se destacava a galinha à cabidela), petiscos, carnes, o de tudo um pouco (prato composto de diferentes pequenas porções ${ }^{98}$ representando a culinária nordestina, peixes, crustáceos, a "refeição simples (para uma pessoa)" e a seção dedicada e as sobremesas. ${ }^{99}$ É nesse Buraco que acontecerá um jantar no qual a pósmodernidade vai ser "apresentada".

Em meados dos anos 1950, um grupo de ilustrados recifenses tinha por hábito reunir-se para discutir os mais variados temas, desde aqueles relacionados à política internacional, nacional ou local até aqueles mais mundanos, como o de quem freqüentava o Hotel Central. Eram "muitas histórias, verdadeiras ou não, contadas sobre os encontros clandestinos que costumavam acontecer nos seus apartamentos [...]. Essa fama, [...] fazia com que o Central fosse olhado com certas restrições". ${ }^{100}$ As reuniões desses ilustrados não se davam em locais fixos, mas sempre em restaurantes, bares ou no Café Lafayette "que marcou profundamente a vida política e social do Recife entre 1919 e o final dos nos 50" ${ }^{101}$ Eram "permanentes" do grupo oito intelectuais de formação acadêmica e ideológica as mais diversas: sociólogo, geógrafo, poeta (anarquista), artista plástico, engenheiro (professo do positivismo), escritor e dois advogados, os demais convivas se chegavam quando "o tempo permitia”. Os encontros, mensais, eram sempre programados ao término do último jantar.

Num determinado dia programado, uma terça-feira, dia preferencial, pois de pouca freqüência nos restaurantes, "Os Bacuraus"102 como se autodenominavam os convivas, começaram, aos poucos, a chegar ao Buraco de Otília. Paulo Cabral, o sociólogo do grupo, e na sequiência o geógrafo João Freire, o anarco-poeta Gilberto Xisto tipógrafo de profissão, Pedro Osório poeta bissexto, Nelson Borges artista plástico, Gilberto Heráclito engenheiro da Rede Ferroviária do Nordeste (RFN), os advogados "José da Hora" para os íntimos, pois o seu nome de batismo era José Grenwitch da Silva e Antonio Tobias, ambos funcionários públicos, na altura também chegou Abelardo Santana que a semelhança do Pedro Osório escrevia, ocasionalmente, na imprensa local. O engenheiro trazia novidades da RFN: ela está se modernizando, estamos adquirindo locomotivas diesel-elétricas, ${ }^{103}$ daqui a Garanhuns vai ser um pulo. Logo que os demais iam chegando, a novidade da modernização da RFN era comentada. O último foi o Nelson Borges as voltas na Biblioteca Pública, tentando decifrar o significado de modernismo. Na realidade, o último a juntar-se ao grupo foi o Xisto que antes passara no quartinho do Buraco para fazer uma precisão, se desfazer dos "líquidos" tomados no Lafayette. O tipógrafo tinha o hábito, como muitos à época, de saírem do trabalho e marcar ponto na esquina da Rua do Imperador ("a rua política do Recife") ${ }^{104}$ com a $1^{\circ}$ de Março, ali no Bar Continental. ${ }^{105} \mathrm{O}$ Tobias provoca: então Xisto já foste moer cana no Lafayette e este contesta - E eu sô home de tomar essas coisas?!, Eu só tomo Fratelli Vita! - no que Osório completou, deixemos de fuleiragem e vamos matar quem nos mata. A escolha recaiu na galinha a cabidela e no prato de tudo um pouco este por possibilitar saborear as diferentes iguarias nordestinas.

\footnotetext{
${ }^{98}$ Recife, como Dona Otília, parecia estar a frente no tempo. Artigo publicado no caderno Cotidiano da Folha de São Paulo de 15 de maio de 2005 tinha o seguinte título: "Cozinha mínima. Em colheres, copinhos ou minixícaras, a moda agora em São Paulo é servir alta gastronomia em doses homeopáticas." A redatora, Giuliana Bastos comenta que "A cartilha minimalista aplicada à gastronomia está levando às últimas consequüências o axioma de que 'menos é mais'. (...) A comida mínima é produzida em doses. São colheres, copinhos, minixícaras que recebem, um a um, pingados ingredientes selecionados com bastante comedimento pelos chefs. A idéia, defendem eles, é fazer com que um resumo de sua cozinha se acomode dentro da concha de uma colher" (BASTOS, 2005, p. C6). Seria pós-moderna esta culinária?

${ }^{99}$ O Buraco de Otília era tão famoso que mesmo à época, não existindo franchising, alguns outros restaurantes se faziam passar por suas filiais. Assim, no cardápio tinha a seguinte informação: Existem alguns restaurantes informando que são nossas filiais. Informamos aos nossos distintos clientes que "O Buraco de Otília não tem filiais". O autor chegou a conhecer nos anos 70 um restaurante nesta mesma cidade com o nome de "Buraquinho". Aliás, é bom lembrar que no cardápio havia uma outra informação: "Atenção! Não aceitamos cheques de terceiros em hipótese nenhuma. Favor não insistir!"

${ }_{100}$ Paraíso, 2004, p. 127-128.

101 "O famoso café comandou as conversas e discussões sobre política e sobre os fatos sociais de maior relevo, de meados dos anos 20 aos finais dos anos 30 . Na década de 40 , fez-se, de certa forma, um ponto não apenas de discussões, mas igualmente de resistência à ditadura Vargas, sobretudo por parte da intelectualidade e da estudantada das nossas escolas superiores. Com a queda de Vargas e instalação de um regime democrático, retomou o antigo prestígio que se manteve até meados dos anos 50 . Alí houve de tudo, até mesmo um duelo esteve perto de ser travado, entre os políticos Amaury Pedrosa e um antigo e truculento ex-chefe de polícia Alarico Bezerra. Mas atraiu tanta gente, congestionou de tal forma a Rua Primeiro de Março e parte da Rua do Imperador, que os bondes nem podiam circular. Por motivos de 'segurança', o duelo foi suspenso e felizmente nunca aconteceu [...]' (MENEZES, p. 24-25).

${ }_{102}^{102}$ Ave noturna.

${ }^{103}$ Bonfim, 2002.

${ }^{104}$ Paraíso, 2001, p. 122.

105 'O nome Lafayette, que 'crismou' a esquina, se deve à charutaria e ponto de cigarros da Fábrica Lafayette, que funcionava no seu pavimento térreo. Já nas primeiras década [do século XX] ninguém mais se referia ao Bar Continental. Aquela era, simplesmente, 'a esquina da Lafayette', ou, mais simplesmente ainda, 'o Lafayette"” (PARAísO, 2001, p. 124).
} 
A conversa começou pelo Borges dizendo estar estudando o modernismo, como artista. O tema me interessa, justificou, no que foi saudado pelos bissextos Osório e Santana. Explicou o Borges que a expressão modernismo foi criada em 1890 pelo poeta nicaragüense Rubén Dario, que a empregou pela primeira vez em um periódico da Guatemala a propósito de uma disputa literária que ocorria no Peru. ${ }^{106}$ Continuando na sua preleção Borges comenta que esta "tímida corrente que levou o nome de modernismo inspirou-se em várias escolas francesas - romântica, parnasiana, simbolista - para fazer uma 'declaração de independência' cultural face à Espanha, que desencadeou naquela década um movimento de emancipação das próprias letras espanholas em relação ao passado" ${ }^{107}$. Todos exclamaram perplexidade pela novidade da informação pois não imaginavam que o termo não tivesse outra origem que não o europeu ou quem sabe, norte-americano, no que Borges acrescentou: Na língua inglesa, meus caros, a "noção de 'modernismo' só passou ao uso geral meio século depois", 108 , na língua de Cervantes "já integrava o cânone da geração anterior" "concluiu o nosso artista plástico.

Borges faz a seguinte e longa apreciação: "Até hoje a grande referência brasileira quando se trata do Modernismo é a Semana de 22 [em São Paulo]. Os registros dos livros apresentam os trabalhos das pintoras Tarsila do Amaral e Anita Malfatti como ícones dessa nova produção. No entanto, como bem se sabe, a lente que registra a história é a dos vencedores. Daí que o modernismo brasileiro seja contado com um protagonismo quase total de São Paulo, eclipsando alguns nomes de fundamental importância $e$ sobrevalorizando outros. É justamente tirando o foco das terras paulistas, e direcionando-o para a periferia, que se revela Pernambuco. O Recife já recebia os novos ares há algum tempo, fazendo uma ponte direta com a Europa, sem precisar da escala no sul do país. Pernambuco era moderno, antes mesmo do Modernismo". ${ }^{110}$

Tomando fôlego e diante dos olhares dos companheiros no Buraco, continua Borges: "Enquanto 1922 se caracteriza como o primeiro tempo modernista no Brasil, quando se vai em busca da atualização internacional das linguagens, para os pernambucanos esse mesmo ano representa a segunda etapa, formalizada pelo uso das novas linguagens para a elaboração de uma arte nacional. Nesse cenário, destaca-se o pintor pernambucano Vicente do Rego Monteiro que, em três pinturas de 22, já revelava seu abstracionismo indianista. [...] Rego Monteiro desenvolveu uma vasta pesquisa sobre os objetos arqueológicos vindos da Amazônia, fez desenhos que ilustravam as lendas indígenas, incorporando aos seus trabalhos valores plásticos característicos da região, explorando as cores terrosas, os volumes e os relevos das cerâmicas dos índios. [...] A audácia e o pioneirismo do pintor pernambucano chegaram a irritar outros nomes fortes da Semana, como o escritor Mario de Andrade, que escreve uma carta, ao também pernambucano Manuel Bandeira, ironizando a opção de Vicente de levar uma exposição internacional de arte moderna vinda de Paris primeiramente a Pernambuco. Escreveu Andrade "São Paulo é o único centro tentável no Brasil, está claro. Esnobismo, não é possível esnobismo nessa mulataria do Brasil, só mesmo em São Paulo, terra européia, cafezistas ricaços etc. (...) Rego Monteiro tinha primeiro que vir pra São Paulo, mas essa gente ainda vive sonhando com a terra natal, parece incrível! Ora, imagine você o Recife do Sr. Gilberto Freyre, comprando um desenhinho de Picasso por três contos (de catálogo)! Depois, se São Paulo não rendesse nada, então tentasse a capital da República e só depois, se de todo não quisesse pôr de banda o coração, então fosse pra terra natal, fazer abluções no Capibaribe, não acha mesmo?""111

Xisto, na sua perplexidade, solta uma: da-lhe mais Borges! Este logo emenda: E dou! Vejam vocês que o "Mário de Andrade, além do poeta Bandeira, tinha certa proximidade com o também modernista pernambucano Cícero Dias, de quem colecionava algumas obras. Contudo, bastou que Dias produzisse, em 1931, sua obra-prima Eu vi o mundo... ele começava no Recife, para que Andrade emudecesse e destacasse

\footnotetext{
${ }^{106}$ Anderson, 1999, p. 9.

107 Ibidem, p. 9

${ }_{108}$ Anderson, 1999, p. 9.

109 lbidem, p. 9.

110 Oliveira, 2008, p. 58. Não podemos esquecer que no século XIX despontava na intelectualidade brasileira a Escola de Recife, movimento de pensadores nordestinos que, das "vicissitudes filosóficas originadas na luta entre a direita e a esquerda hegelianas, [...], nasceriam 'grandes alavancas com que se combateu a velha mentalidade brasileira'. Um mestiço, o germanista sergipano Tobias Barreto, abriria, no [nordeste] do País, uma janela escancarada pela qual entraria 'uma rajada de pensamento livre, de cultura moderna que fecundou numerosos espíritos"' (COSTA, 1967, p. 278).

11 Oliveira, 2008, p. 58-59.
} 
apenas outros trabalhos expostos no Salão Revolucionário. ${ }^{112}$ [O] modernismo nas artes plásticas foi pioneiro, sim, no Recife ${ }^{\text {113 }}$. Complementa Xisto: Pernambuco falando para o mundo!. ${ }^{114}$

Surpresos ficaram quando ele ainda mantendo a explanação diz: e se vocês não sabem fiquem sabendo pois já se fala em pós-modernismo, pois é, pois é. O conceito foi criado no mundo "hispânico, na década de 1930, uma geração antes do seu aparecimento na Inglaterra ou nos Estados Unidos. Foi um amigo de Unamuno ${ }^{115} e$ Ortega ${ }^{116}$ Frederico de Onís, quem imprimiu o termo postmodernismo". ${ }^{117}$ Porém, segue Borges, como tudo tem um porém, "a idéia de um estilo 'pós-moderno' entrou para o vocabulário da crítica hispanófona, [...] mas não teve maior ressonância. Só uns vinte anos depois o termo surgiu no mundo anglófono, num contexto bem diferente - como categoria de época e não de estética"118 enfatizou Borges. Já com a "galinha" e as "diferenças" sendo servidas, a tertúlia tem continuidade com a seguinte frase do nosso artista plástico: agora, neste meado dos nossos anos 50, a expressão retorna ${ }^{119}$ e terá uma maior difusão nas próximas décadas. ${ }^{120}$ No que foi amparado pelo seguinte comentário do engenheiro Heráclito: nós estamos na sociedade industrial, a prática da modernidade, quem sabe não chegaremos a pós-industrial, pois poderemos ligar pós-modernidade com pós-industrial. ${ }^{121}$

A palavra ainda está com o Borges, o "traço definidor da condição pós-moderna, (...), é a perda da credibilidade [nas] metanarrativas. (...) elas foram desfeitas pela evolução imanente das próprias ciências: por um lado através de uma pluralização de argumentos, com a proliferação do paradoxo e do paralogismo (...); e, por outro lado, por uma tecnificação da prova, na qual aparatos dispendiosos comandados pelo capital ou pelo Estado reduzem a 'verdade' ao desempenho. A ciência a serviço do poder encontra uma nova legitimação na eficiência. (...) A condição pós-moderna, é a tendência para o contrato temporário em todas as áreas da existência humana: a ocupacional, a emocional, a sexual, a política - laços mais econômicos, flexíveis e criativos que os da modernidade". ${ }^{122}$ Com a garganta já seca grita o Borges em direção a cozinha do Buraco: Otília, trás mais uma pinga! Ainda tenho o que dizer - e concluiu - o significado de pós-modernidade meus confrades "se tornou a inspiração de um relativismo vulgar que muitas vezes, tanto aos olhos dos amigos quanto dos inimigos, passa por ser a [sua] marca". ${ }^{123}$

A síntese da explanação do Borges sairia da boca do ácrata Xisto: não percamos mais tempo, se bem entendi o pluralismo, a proliferação, o temporário, a flexibilidade, enfim, a diferença são os traços centrais da pósmodernidade. No que Heráclito comenta: Não entendi. O que foi imediatamente aparteado por Xisto: é simples, a pós-modernidade está a nossa frente, faz parte do cardápio de Otília, o prato de tudo um pouco, vejam que são pequenos recipientes de barro, do tamanho de um pires, vários, mais de dez pratinhos contendo diferentes comidas da culinária nordestina. Comemos de tudo um pouco mas, o que fica na memória? Apenas traços de

\footnotetext{
112 "É como Salão Revolucionário que fica conhecida a 38 Exposição Geral de Belas Artes, de 1931, em razão de ter abrigado, pela primeira vez, artistas de perfil moderno e modernista. Realizado no curto período de Lucio Costa (1902 - 1998) na direção da Escola Nacional de Belas Artes - Enba, de 1930 a 1931, o Salão Revolucionário sinaliza o esforço do arquiteto de modernizar o ensino de arte no país e de abrir as mostras oficiais, até então dominadas pelos artistas acadêmicos, à arte moderna. A própria composição da comissão organizadora do Salão, a partir de então, indica sua vocação renovadora: além de Lucio Costa, Manuel Bandeira (1886 1968), Anita Malfatti (1889 - 1964), Candido Portinari (1903 - 1962) e Celso Antônio , todos ligados ao movimento moderno" (http:www.itaucultural.org.br, acessado em 08 de dezembro de 2008).

113 Oliveira, 2008, p. 59

${ }^{114}$ A expressão Pernambuco falando para o mundo era o slogan da Rádio Jornal do Commercio, inaugurada em 1948 que pertencia ao Grupo de Fernando Pessoa de Queiroz, juntamente com dois jornais: Jornal do Commércio (funcionando) e o Diário da Noite (extinto). Várias rádios também pertenciam ao grupo, seja em Recife, na zona da mata e no agreste pernambucano, como as rádios de Limoeiro e Garanhuns. Disponível no site http://www.jornalismo.ufsc.br/redealcar/GT/historia. Acessado em 24.08.2004.

${ }^{115}$ Miguel de Unamuno (1864-1936), filósofo espanhol.

116 José Ortega y Gasset (1883-1955), filósofo espanhol.

117 Anderson, 1999, p. 10.

118 Ibidem, p. 10.

${ }^{119}$ Anderson, 1999 , p. 18

120 Ibidem, p. 20. Borges tinha razão, pois "o momento realmente decisivo veio com o lançamento, no outono de 1972, de uma publicação que trazia expressamente o subtítulo Revista de Literatura e Cultura Pós-Moderna - o periódico boundary 2 [fronteira 2]" (ANDERSON, 1999, p. 23). E a "primeira obra filosófica a adotar a noção foi $A$ condição pós-moderna, de Jean-François Lyotard, publicada em Paris em 1979"(ANDERSO, 1999, p. 31). Portanto, "foi o primeiro livro a tratar a pós-modernidade como uma mudança geral na condição humana. [...] continua até hoje talvez a obra mais citada sobre o assunto" (ANDERSON, 1999, p. 33).

${ }^{121}$ Anderson, 1999 , p. 32.

122 Ibidem, p. 32-33.

${ }^{123}$ Ibidem, p. 34.
} 
uma cultura. Substancialmente, um forâneo não iria perceber a qualidade da nossa culinária comendo de tudo um pouco. Eis a pós-modernidade. ${ }^{124}$

O calado "José da Hora" achou que agora era o momento de falar. Senhores, "positivamente, [...], o pósmodernismo [é uma] legítima reação à 'monotonia' da visão de mundo do modernismo universal. 'Geralmente percebido como positivista, tecnocêntrico e racionalista, o modernismo universal tem sido identificado como a crença no progresso linear, nas verdades absolutas, no planejamento racional de ordens sociais ideais, e com a padronização do conhecimento e da produção'. O pós-moderno, em contraste, privilegia 'a heterogeneidade e a diferença como forças libertadoras na redefinição do discurso cultural'. A fragmentação, a indeterminação e a intensa desconfiança de todos os discursos universais ou (para usar um termo favorito) 'totalizantes' são o marco do pensamento pós-moderno. [...] $O$ que há [na concepção pós-moderna] é a rejeição das 'metanarrativas' (interpretações teóricas de larga escala pretensamente de aplicação universal)', 125

Terminada a xepa, regalados pela culinária de Otília e em progresso, todos retornaram as suas casas, uns de bonde, outros de trem e outros, simplesmente, andando por entre as ruas da "Veneza Brasileira". Uns atravessando o Capibaribe e ainda aqueles que teriam que faze-lo pelo Beberibe.

\section{Rua de Janus, s/n.}

Voltemos ao Rio de Janeiro ao término da Rua do Ouvidor onde teríamos, pelo menos, três opções de direção ao sairmos do 132. Seguindo em frente poderíamos chegar ao Largo de São Francisco de Paula e entrar no IFCS (Instituto de Filosofia e Ciências Sociais) da UFRJ (Universidade Federal do Rio de Janeiro). Alí chegando, poderíamos aprender os significados ou as interpretações de modernidade e pós-modernidade. Se o caminhante não deseja esta opção e quer caminhar por "suas próprias pernas", valeria a pena refletir, mais uma vez, sobre o conteúdo destas duas categorias centrais do pensamento ocidental - modernidade e pósmodernidade porém, antes, considerando a "face de Janus" da própria modernidade.

Dada a sua origem iluminista a modernidade traçou dois caminhos: um deles poderia contribuir para a emancipação do homem; o outro o submeteria aos parâmetros do desempenho. Ou seja, desde a modernidade ou caminhamos em busca da liberdade e da igualdade, da liberdade positiva, quando o outro isonomicamente está presente; ou caminhamos em busca da eficiência, da produtividade, da liberdade negativa, ${ }^{126}$ quando o outro resta. No primeiro caso o homem por meio da razão libertou-se dos mitos, deuses e demônios assim como disporia das categorias para a sua autoconsciência criticando a própria razão. No segundo caso, a busca do desempenho o levaria a submissão da racionalização dos meios em detrimento dos fins. A modernidade do primeiro caminhar é a normativa. Ao ser "esboçada pelo Iluminismo, a técnica está a serviço do homem e a esfera cultural é autenticamente secularizada, ou seja, o homem se liberta do mito e as energias utópicas da tradição migram para a esfera da práxis, historicizando-se". ${ }^{127}$ Por sua vez, a modernidade em busca do desempenho e acoplada ao capitalismo, "se afasta do modelo normativo, porque nela a técnica é instrumento de opressão e a esfera cultural secularizou-se no pior sentido, deixando intacto o mito, que agora se confunde com

\footnotetext{
124 "O pendor para o informe e o atípico, para o desgarrado e o eventual, para o mutante e o volátil, trai um gosto difuso que se assume como já não mais moderno e, daí, à falta de melhor termo ou de imaginação conceitual, pós-moderno" (BOSI, 1992, p. 353).

${ }^{125}$ Harvey, 1992, p. 19. No dizer de Luis Carlos Fridman, Jean-François Lyotard horrorizado e decepcionado com "as conseqüências da razão, [...] construiu os argumentos de $A$ condição pós-moderna. A falência das grandes narrativas da modernidade que explicavam e ordenavam o presente e apontavam para bonanças no futuro, mostrou a agonia das grandes produções de sentido que associavam progresso, revolução e auto-realização. A concretização das aspirações despertadas pelo lluminismo em projetos de ordem desfez credulidades, e Lyotard, atento a essas novas condições, interpretou a pós-modernidade como uma cultura permeada de parcialidade e provisoriedade. Propôs a validação das narrativas modestas a partir das comunidades de origem e a valorização das diferenças na nova pluralidade" (FRIDMAN, 2000, p. 43).

126 "Nas ciências do direito, tornou-se natural nesse meio tempo efetuar uma distinção dos direitos subjetivos em direitos liberais de liberdade, direitos políticos de participação e direitos sociais de bem-estar; a primeira categoria refere-se aos direitos negativos que protegem a pessoa de intervenções desautorizadas do Estado, com vista à sua liberdade, sua vida e sua propriedade; a segunda categoria, aos direitos positivos que lhe cabem com vista à participação em processos de formação pública da vontade; e a terceira categoria, finalmente, àqueles direitos igualmente positivos que a fazem ter parte, de modo eqüitativo, na distribuição de bens básicos"(HONNETH, 2003, p. 189).

${ }^{127}$ Rouanet, 1993, p. 70.
} 
a realidade". ${ }^{128}$ Sob o desempenho a sociedade é segmentada em função da execução econômica e concorrente de seus membros.

O princípio do desempenho, [...], pressupõe um longo desenvolvimento durante o qual a dominação foi crescentemente racionalizada: o controle sobre o trabalho social reproduz [...] a sociedade numa escala ampliada e sob condições progressivas. [...] Para a esmagadora maioria da população, a extensão e o modo de satisfação são determinadas pelo seu próprio trabalho; mas é o trabalho para uma engrenagem que ela não controla, que funciona como um poder independente a que os indivíduos têm de submeter-se se querem viver. [...] Os homens não vivem a sua própria vida, mas desempenham tão-só funções pré-estabelecidas. Enquanto trabalham, não satisfazem suas próprias necessidades e faculdades, mas trabalham em alienaçãol29 (grifo do autor). 130

No dizer de François Lyotard as universidades e as instituições de ensino superior não são mais solicitadas a formar ideais, mas sim competências: "tantos médicos, tantos professores de tal ou qual disciplina, tantos engenheiros, tantos administradores, etc." ${ }^{131}$ A transmissão dos saberes não está destinada a orientar o homem em busca da sua emancipação, mas "fornecer jogadores capazes de assegurar convenientemente seu papel junto aos postos pragmáticos de que necessitam as instituições". ${ }^{132}$ De forma ainda mais contundente complementa:

A questão explícita ou não, apresentada pelo estudante profissionalizante, pelo Estado ou pela instituição de ensino superior não é mais: isto é verdadeiro?, mas: para que serve isto? No contexto da mercantilização do saber, esta última questão significa comumente: isto é vendável? E, no contexto do aumento do poder: isto é eficaz? [O que estudas elou praticas garante a tua empregabilidade?] [...] $O$ que deixa de existir 'é a competência segundo' critérios como verdadeiro/falso, justo/injusto, etc.133

O indivíduo que deseja emancipar-se é aquele que se opõe à racionalidade instrumental, racionalidade que tem origem na divisão social do trabalho "e que no mundo moderno alcança um ilimitado poder". ${ }^{134}$ Portanto, o ser soberano não se deixaria reduzir, como acontece no mundo do trabalho, "ao estado de uma coisa" "135. Porém, esta soberania é vítima de "um processo histórico universal de desencantamento e objetivação"136 uma vez que nas sociedades modernas o indivíduo, para sobreviver, fica dependente de seu potencial de desempenho, de sua utilidade em um universo reificado. Daí a necessidade de uma pedagogia emancipadora que, no dizer de Gagnebin, citando Adorno, "geralmente só atinge aqueles que já estão abertos a ideais emancipatórios, isto é, aqueles que não precisam, para sobreviver, se 'identificar' a qualquer custo 'com o existente', com o dado". 137 A palavra-chave para uma pedagogia emancipadora não é racionalidade, meios, recursos, empregabilidade etc. mas esclarecimento. Lembrando que esta palavra - esclarecimento é usada cotidianamente como "explicação, explicitação, clarificação ou atividade pedagógica racional de colocar claramente um problema"138 e o problema dos estudos organizacionais, predominantemente, está voltado para o desempenho e não para a emancipação. A utilidade é o que interessa e não a liberdade e igualdade no interior do mundo do trabalho.

Se aceitarmos que o prefixo pós-, o que vem depois, vai definir uma nova configuração estrutural à modernidade, portanto viveríamos uma época pós-moderna, consequentemente a modernidade já estaria envelhecida. ${ }^{139}$ Porém, o que envelheceu não foi a modernidade como projeto, mas a maneira como ela está

\footnotetext{
${ }_{128}^{128}$ Ibidem, p. 71.

${ }^{129}$ Sob a alienação "o homem não se realiza em seu trabalho, [e] a sua vida se tornou um instrumento de trabalho, [além do que,] o seu trabalho e os respectivos produtos assumiram uma forma e um poder independente dele como indivíduo" (MARCUSE, 1968, p. 103).

${ }_{130}$ Marcuse, 1968, p. 58.

${ }^{131}$ Lyotard, 2006, p. 89.

132 Lyotard, 2006, p. 89.

133 Ibidem, p. 93.

${ }^{134}$ Habermas, 1989, p. 269.

135 Ibidem, p. 269.

136 Ibidem, p. 269.

${ }_{137}^{137}$ Gagnebin, 2006, p. 103.

138 Ibidem, p. 101.

139 "O conceito de pós-modernidade ou pós-modernismo se converteu em um dos conceitos mais esquivos na discussão estética, literária e sociológica da última década. O termo pós-modernidade pertence a uma rede de conceitos e pensamento 'pós' - sociedade pósindustrial, pós-estruturalismo, pós-empirismo, pós-racionalismo - nos quais, segundo parece, trata de articular-se a si mesma a consciência de uma mudança de época, consciência cujos contornos são ainda imprecisos, confusos e ambivalentes, porém cuja experiência central, a morte da razão, parece anunciar o fim de um projeto histórico: o projeto da modernidade, o projeto da llustração européia, ou finalmente também o projeto da civilização grega e ocidental" (WELLMER, 1995: 319). Ou no dizer de Beatrice Hanssen: "Quer fosse uma questão de pós-iluminismo, de pós-estruturalismo, de pós-modernidade ou de pós-história [...], o prefixo temporal "pós"
} 
sendo realizada. "Não são a razão, a ciência e a liberdade que se tornam obsoletas, e sim um certo uso da razão, da ciência e da liberdade". ${ }^{140}$ No caso específico da Administração como área de conhecimento, a sua mística em torno da busca pelo melhor desempenho, pela produtividade incrementada, pela eficiência do sistema, do mundo do trabalho, na realidade, tem ampliada a reificação do trabalhador uma vez que o processo produtivo, de bens ou serviços, segundo os cânones mais recentes da tecnologia da informação, tem ampliado o controle de suas ações, independente da distância a que se encontre do local de tomada de decisão. ${ }^{141}$ Como ato de modernização, de tornar-se moderno, as técnicas oriundas da Administração cumprem seu papel enquanto fundamento para o mito do progresso linear e automático, da permanente obsolescência tecnológica da racionalização. ${ }^{142}$ No enanto, "em seu sentido normativo ${ }^{143}$ e teleológico ${ }^{144}$, a modernidade não envelheceu, pela simples razão de que nunca se realizou. A tarefa política é acelerar o envelhecimento da modernidade empírica [desempenho], para abrir espaço à modernidade normativa [emancipadora], com sua razão dialética, sua ciência libertadora e sua liberdade concreta". ${ }^{145}$

A questão que se coloca à Administração como ciência social e/ou técnica, é se ela é capaz de atender à modernidade enquanto categoria emancipadora na medida em que, enquanto desempenho, o ato de gerenciar já ocorria antes mesmo do advento da divisão organizacional do trabalho. Uma vez que "o primeiro trabalho funda o mundo das coisas [desde] a posição do mundo das coisas, o homem mesmo converteu-se em uma das coisas deste mundo, pelo menos, durante o tempo em que trabalha" ${ }^{146}$ Na relação sujeito-objeto e dado a modernização dos processos produtivos, o trabalhador passa a ser um recurso, uma coisa a ser administrada, portanto é uma relação protagonizada pela reificação ou utilidade dessa relação. ${ }^{147}$ Ainda usando a referência de Habermas a partir da Georges Bataille (1897-1962) complementamos esta relação uma vez que:

[...] 'Por obra de uma acumulação de riquezas destinadas a por em marcha uma produção industrial [e pós-industrial] de dimensões crescentes, a sociedade burguesa é a sociedade das coisas. Esta sociedade, em comparação com a imagem da sociedade feudal, não é uma sociedade de pessoas [...] $O$ objeto transformado em dinheiro vale mais que o sujeito, o qual, desde que passa a depender dos objetos (ao possuir estes), já não existe para si mesmo nem possui dignidade alguma.' Porém, em realidade, o fetichismo da forma mercadoria somente serve à extensão e propagação universais da dominação de uma razão calculadora, fincada já antropologicamente nas estruturas do trabalho. ${ }^{148}$

marcava uma 'falsa separação' da modernidade e, por implicação, uma falsa consciência o tempo, reminiscente da modernidade estética" (HANSSEN, 2008, p. 331), e não da modernidade política como é o desejo de Jürgen Habermas.

${ }^{140}$ Rouanet, 1993, p. 73.

141 "Com a racionalização do mecanismo produtivo, com a multiplicação de funções, toda a dominação assume a forma de administração. No seu auge, a concentração do poder econômico parece converter-se em anonimato; todos, mesmo os que se situam nas posições supremas, parecem impotentes ante os movimentos e leis da própria engrenagem. O controle é normalmente administrado por escritórios em que os controlados são os empregadores e empregados. Os patrões já não desempenham uma função individual. Os chefes sádicos, os exploradores capitalistas, foram transformados em membros assalariados de uma burocracia, com quem os seus subordinados se encontram, como membros de outra burocracia. [...] O impulso agressivo mergulha no vácuo - melhor, o ódio encontrase com sorridentes colegas, atarefados concorrentes, funcionários obedientes, prestimosos trabalhadores [...], que estão todos cumprindo seus deveres e são todos vítimas inocentes" (MARCUSE, 1968, p. 98).

142 "Para dizer a verdade, a modernização foi entendida até agora, exclusivamente, como uma intervenção, dos centros hegemônicos nas áreas periféricas dependentes, como colonização e integração do mundo subdesenvolvido ao mercado capitalista internacional; em suma, como um intento de 'ocidentalização', 'europeização', ou 'norte-americanização'. Nos últimos tempos, não obstante, se comprova uma sempre maior receptividade frente a uma idéia diferente de modernização, uma idéia que, desde uma certa ótica, aparece bastante próxima a aquela do 'processo civilizador', tal como foi tratada por Norbert Elias y Darcy Ribeiro. Portanto, vai delineando-se uma modernização que assume, como princípio, a tradição da modernidade, a 'grande tradição não tradicional', ainda que submetida constantemente à valorização crítica do que temos chamado de projeto moderno, isto é, um projeto centrado na emancipação" (MALDONADO, 1995, p. 263).

143 Definição de padrões de comportamento que determinam o que é correto, bom etc.

${ }_{145}$ A busca de fins últimos que orientam a humanidade para o seu bem-estar.

${ }^{145}$ Rouanet, 1993, p. 73.

${ }^{146}$ Bataille apud Habermas, 1989, p. 271.

147 "O homem sofre os contragolpes da divisão social do trabalho, por mais que ela favoreça o desempenho exigido. [...] Assim como, sob o primado absoluto do processo de produção, desaparece a finalidade da razão, até ela rebaixar-se ao nível do fetichismo de si mesma e do poder exterior, assim também ela se transforma de novo num instrumento, igualando-se a seus funcionários, cujo aparato intelectual serve apenas à finalidade de impedir o pensar. [...] Que em tudo isso se trata de tendências que já estão muito avançadas, é algo que se mostra a cada passo na empresa da ciência, que está a ponto de subjugar os restos do mundo, um amontoado de destroços indefesos" (ADORNO, 1992, p. 106-107.).

${ }^{148}$ Habermas, 1989, p. 270. 
Assim, retornando não mais à Rua do Ouvidor ou à Rua da Aurora, mas a Rua de Janus, a sugestão é considerar o pensamento de Jürgen Habermas da segunda geração da Teoria Crítica, ${ }^{149}$ que rejeita a crítica da primeira geração, notadamente de

Horkheimer, Adorno e Marcuse, afirmando que a razão Esclarecida apresenta uma dupla face de Janus de possibilidades, algumas boas e outras más. Isso lhe permitiu vislumbrar a emancipação não como uma superação histórica do Esclarecimento, mas como necessitando da identificação das formas no interior do Esclarecimento que poderiam ser colocadas a serviço da emancipação e da autonomia. $^{150}$

Apesar de ser um texto aberto à discussão, o autor assume que a dicotomia modernidade versus pósmodernidade poderia ser analisada sob um continnum de possibilidades onde combinações dialéticas ocorrem entre os dois pólos. ${ }^{151}$ Isto é, os conteúdos de ambos os conceitos permitem perceber que, apesar de um deles posicionar-se como posterior, traz dentro de si substâncias do precedente contrariando, assim, a sua intenção de ser diferente, de ser pós. Dialeticamente "enxergar o novo no velho, em vez de simplesmente o velho no novo". ${ }^{152} \mathrm{O}$ antecedente estando presente no conseqüente, estabelece as estruturas que definem a dissemelhança. Mesmo com pretensões de ser distinta, a pós-modernidade contém a modernidade na sua intenção original, ilustrar, marcando a diferença entre o deificado e o laicizado. Os pós-modernos podem acreditar que as premissas da modernidade estão mortas, ${ }^{153}$ mas as suas "consequiências continuam em marcha" "154 uma vez que a emancipação do homem é fim e não desempenho, meio. E a questão que fica é se a Administração, como uma das áreas das ciências sociais, por ser rotulada de aplicada, não estaria mais voltada para o desempenho do que à emancipação uma vez que seguiu a "peripécia no drama da razão". ${ }^{155}$ Parece ser que a Administração procura ser apenas moderna, ou praticar a modernização não trilhando o caminho que a modernidade originalmente nos ensinou, que é a busca permanente pela igualdade e liberdade, seguir o caminho da razão não como defensora dos meios mas dos fins.

Os filósofos do Iluminismo, [...], ainda tinham a extravagante esperança de que as artes e as ciências promoveriam não somente o controle das forças da natureza mas, também, a compreensão do mundo e do indivíduo, o progresso moral, a justiça das instituições e a felicidade dos homens. Nosso século alterou este otimismo. A diferenciação da ciência, da moral e da arte desembocou na autonomia de segmentos manipulados por especialistas e dissidentes da hermenêutica da comunicação diária. [Deveríamos] tratar de reviver as intenções do Iluminismo, ou reconhecer que todo o projeto da modernidade é uma causa perdida? [...] Em uma palavra: o projeto da modernidade ainda não foi realizado. [...] O mundo da vida deverá ser capaz de desenvolver instituições que ponham limites a dinâmica interna e aos imperativos de um sistema econômico quase autônomo e aos seus instrumentos administrativos. ${ }^{156}$

\footnotetext{
${ }^{149}$ Conhecida também como Escola de Frankfurt.

${ }^{150}$ Chambers, 2008, p. 275-276.

151 "Ser moderno é encontrar-se em um ambiente que promete aventura, poder, alegria, crescimento, autotransformação e transformação das coisas em redor - mas ao mesmo tempo ameaça destruir tudo o que temos, tudo o que sabemos, tudo o que somos. A experiência ambiental da modernidade anula todas as fronteiras geográficas e raciais, de classe e nacionalidade, de religião e ideologia: nesse sentido, pode-se dizer que a modernidade une a espécie humana. Porém, é uma unidade paradoxal, uma unidade de desunidade: ela nos despeja a todos num turbilhão de permanente desintegração e mudança, de luta e contradição, de ambigüidade e angústia. Ser moderno é fazer parte de um universo no qual, como disse Marx, 'tudo que é sólido desmancha no ar"' (BERMAN, 1986, p. 15).

152 Jay, 2008, p. 114.

153 "A esta altura, me permito assinalar que não creio que toda cultura contemporânea seja pós-moderna, nem sequer o seja de forma preponderante. No entanto, existem vários tipos de objetos culturais em circulação ao mesmo tempo: modernos, realistas e prérealistas, como os objetos culturais góticos e cristãos. Segundo, muitos objetos culturais empiricamente existentes mostram uma combinação de traços realistas, modernistas e pós-modernistas. Portanto, utilizo 'pós-modernismo' e 'modernismo' como tipos ideais. [...] Entretanto, o esquema global deste livro supõe que os objetos culturais modernos surgem com força nos finais do século XIX e que o pós-modernismo começa a surgir de forma significativa nas três últimas décadas" (LASH, 2007, p. 31).

${ }_{154}^{154}$ Habermas, 1989, p.13.

155 Habermas, 1989, p. 291.

156 Ibidem, 1995, p. 142. Habermas, neste mesmo texto, comenta que o anti-modernismo encontra-se em três tipos: jovens conservadores - "recuperam a experiência básica da modernidade estética. Reclamam como próprias as revelações de uma subjetividade descentrada, emancipada dos imperativos do trabalho e da utilidade, e com esta experiência dão um passo fora do mundo moderno. [...] Na França esta linha [de pensamento] vai de Georges Bataille, via Michel Foucault a Derrida;" velhos conservadores - "não se permitem a contaminação com o modernismo cultural. Observam com tristeza o declínio da razão substantiva, a especialização da ciência, a moral e a arte, a racionalidade de meios do mundo moderno. [...] Nesta linha, que se origina em Leo Strauss, podem ser encontrados obras interessantes como as de Hans Jonas e Hobert Spaemann;". Finalmente os neo-conservadores - "saúdam o desenvolvimento da
} 
Finalmente, por ser um ensaio e como já foi advertido no I. Esclarecimento, este texto não tem nenhuma pretensão concludente, comprobatório. É um desejo de resistência. ${ }^{157}$ Pelo contrário, o seu intento foi novamente, colocar em pauta, ainda que sem nenhuma pretensão e de forma lusório-gastronômica, uma discussão que faz parte do pensamento crítico, notadamente o frankfurteano, tanto da primeira quanto da segunda geração, que é discutir as categorias enfocadas - moderno, modernidade, modernização e pósmodernidade ${ }^{158}$ Embora a primeira geração frankfurteana tenha sido pessimista enquanto as possibilidades propostas pela modernidade, ${ }^{159}$ a segunda geração, particularmente Jürgen Habermas, trata o tema como a possibilidade do ser humano, intersubjetivamente, emancipar-se do jugo da racionalidade instrumental, da racionalidade voltada para o desempenho, por uma outra racionalidade, a comunicativa, sob a qual todos tenham o direito a fala desde que vocalizando argumentos fundamentados na liberdade e na igualdade, na busca daquilo que se propôs a modernidade, que é a conjunção da liberdade com a razão.

A verdadeira gênese não se situa no começo, mas no fim, e ela apenas começará a acontecer quando a sociedade e a existência se tornarem radicais, isto é, quando se apreenderem pela raiz. Porém, a raiz da história é o ser humano trabalhador, produtor, que remodela e ultrapassa as condições dadas. Quando ele tiver apreendido a si mesmo e ao que é seu sem alienação, surgirá no mundo algo que brilha para todos na infância e onde ninguém esteve ainda: a pátria. Ernst Bloch ${ }^{160}$

ciência moderna, na medida em que possibilite o progresso técnico, o crescimento capitalista e a administração racional. [...] Nesta linha poderiam incluir-se o primeiro Wittgenstein, Carl Schmitt em sua segunda etapa e Gottfried Benn, em seu último momento" (HABERMAS. 1995, p. 143, grifos nosso).

157 "O pensamento crítico, inconformista, que se empenha em questionar as construções 'acabadas', beneficia-se da forma do ensaio, mas admite que se defronta com dificuldades ao refletir sobre ela. [...] A força do ensaio está muito mais naquilo que ele recusa do que na clareza e na coerência daquilo que propõe. A situação do ensaio em um tanto paradoxal. [O] ensaio assimila algo da liberdade de expressão aprendida na arte, porém, não é, a rigor, um gênero artístico" (KONDER, 2005, p. 44).

158 "Esta tipologia é, como são todas as tipologias, uma simplificação, ainda que não de todo inútil para a análise das confrontações intelectuais e políticas contemporâneas" (HABERMAS, 1995, p. 144).

${ }^{159}$ Os textos de Max Horkheimer e Theodor Adorno Dialética do esclarecimento (Rio de Janeiro: Jorge Zahar Ed., 1985) e Eclipse da razão de Max Horkheimer (São Paulo: Centauro, 2000), explicitam sobremaneira esta posição, já a segunda geração frankfurteana à frente Jürgen Habermas, através do seu livro Teoria de la acción comunicativa, volumes I e II (Madrid: Taurus, 1987), sustenta a possibilidade da modernidade por meio de uma prática intersubjetiva da razão.

${ }^{160}$ Bloch, 2006, p. 462. 


\section{Referências bibliográficas}

ADORNO, Theodor. Mínima moralia: reflexões a partir da vida danificada. São Paulo: Ática, 1992.

ANDERSON, Perry. As origens da pós-modernidade. Rio de Janeiro: Jorge Zahar Editor, 1999.

ASSIS, Machado. "Capitulo dos chapéus." In: Contos Porto Alegre: L \& PM, 2008.

BASTOS, Giuliana. "Cozinha mínima" In: Cotidiano - Folha de São Paulo São Paulo: Folha de São Paulo, 15 de maio de 2005.

BERMAN, Marshall. Tudo o que é sólido desmancha no ar. A aventura da modernidade. São Paulo: Companhia das Letras, 1986.

BERNARDINO, Bertrando. Minidicionário de pernambuquês. Recife: Bagaço, 202, 3ª ed.

BLOCH, Ernst. 0 principio esperança. Rio de Janeiro: EdUERJ: Contraponto, 2006, v. 3.

BOMFIM, Luiz Ruben F. de A. Estrada de Ferro Central de Pernambuco Paulo Afonso (BA): Graf Tech, 2002.

BOSI, Alfredo. Dialética da colonização. São Paulo: Companhia das Letras, 1992.

BRAGA, João. Trilhas do Recife: guia turístico, histórico e cultural. Recife: João Braga, 2002.

CARPEGGIANI, Schneider. "A bela época na Esquina do Lafayette" In: http://www2.uol.com.br/JC/_2001/2905/cc2905_1.htm acessado em 24.08.2004

CAVALCANTI, Carlos Bezerra. O Recife e suas ruas. Recife: Edições Edificantes, 2002.

0 Recife: pontos de encontro. Recife: Edições do Autor, 1999.

CHAMBERS, Simone. "A política da Teoria Crítica" In: RUSH, Fred (Org.) Teoria Crítica Aparecida, SP: Idéias \& Letras, 2008.

COMER e beber com Eça de Queiroz. Rio de Janeiro: Editora Índex, 1995.

COSTA, Cruz. Contribuição à história das ideias no Brasil. Rio de Janeiro: Civilização Brasileira, 1967.

DICIONÁRIO ELETRÔNICO HOUAISS DA LÍNGUA PORTUGUESA Rio de Janeiro: Objetiva, 2002.

Du MARSAIS, César Chesneau. Filosofia clandestina: cinco tratados franceses do século XVIII. São Paulo: Martins, 2008.

EDITORA INDEX Comer e beber com Eça de Queiroz. Rio de Janeiro: Editora Index, 1995.

FRIDMAN, Luis Carlos. Vertigens pós-modernas: configurações institucionais contemporâneas. Rio de Janeiro: Relume Dumará, 2000.

GAGBIN, Jeanne Marie. Lembrar escrever esquecer. São Paulo: Ed. 34, 2006.

GARCIA, Sérgio. Rio de Janeiro - passado e presente. Rio de Janeiro: Conexão Cultural, 2000.

GERSON, Brasil. História das ruas do Rio. Rio de Janeiro: Livraria Brasiliana Editora, 1965, 4ª. ed. (revista, ampliada e ilustrada).

GIANNETTI, Eduardo. 0 livro das citações: um breviário de ideias replicantes. São Paulo: Companhia das Letras, 2008.

HABERMAS, Jürgen. El discurso filosófico da la modernidad. Madrid: Taurus, 1989.

"Modernidad: um proyecto incompleto". In: CASULLO, Nicolas (Comp.) El debate modernidad/posmodernidad. Buenos Aires: El Cielo Por Asalto, 1995, 5a. ed.

HANSEN, Beatrice. " Teoria Crítica e o pós-estruturalismo: Habermas e Foucault." In: RUSH, Fred (Org.) Teoria Crítica Aparecida, SP: Idéias \& Letras, 2008.

HARMON, Michael M. e MAYER, Richard T. Teoría de la organización para la Administración Pública México (DF): Fondo de Cultura Econômica, 1999.

HARVEY, David. Condição pós-moderna. São Paulo: Edições Loyola, 1992.

HOBSBAWN, Eric J. A era das revoluções: 1789-1848. São Paulo: Paz e Terra, 2004, 18a. ed.

HONNETH, Axel. Luta por reconhecimento: a gramática moral dos conflitos sociais. São Paulo: Editora 34, 2003. 
JAMENSON, Frederic. Modernidade singular. Rio de Janeiro: Civilização Brasileira, 2005.

JAPIASSU, Hilton e MARCONDES, Danilo. Dicionário básico de Filosofia. Rio de Janeiro: Jorge Zahar Editor, 1990.

JAY, Martin. A imaginação dialética: história da Escola de Frankfurt e do Instituto de Pesquisas Sociais, 1923-1950. Rio de Janeiro: Contraponto, 2008.

JOHNSON, Allan G. Dicionário de Sociologia: guia prático da linguagem sociológica. Rio de Janeiro: Jorge Zahar Editor, 1997.

KANIGEL, Robert. The one best way: Frederick Winslow Taylor and the enigma of efficiency. New York: Viking, 1997.

KANT, Immanuel. Textos seletos. Petrópolis, RJ: Vozes, 2008, 4a. ed.

KONDER, Leandro. As artes da palavra: elementos para uma poética marxista. São Paulo: Boitempo, 2005.

LASH, Scott. Sociología del posmodernismo. Buenos Aires: Amorrortu, 2007, 2ª. ed.

LYOTARD, Jean-François. A condição pós-moderna. Rio de Janeiro: José Olímpio Editora, 2006.

MACEDO, J. M. Memórias da Rua do Ouvidor Brasilia: Editora Universidade de Brasília, c1988.

MALDONADO, Tomás. "El movimiento moderno y la custión 'post'." In: CASULLO, Nicolas (Comp.) El debate modernidad /posmodernidad. Buenos Aires: El Cielo Por Asalto, 1995, 5a. ed.

MARCUSE, Herbert. Eros e civilização: uma interpretação filosófica do pensamento de Freud. Rio de Janeiro: Zahar Editores, 1968.

MENEZES, Fernando. Coisas do Recife Recife: Edições Bagaço, 2004, 2ª edição.

OLIVEIRA, Mariana. "E vi o Modernismo... Ele começava no Recife" In: Continente Multicultural Recife: Companhia Editora de Pernambuco - CEPE, ano VIII, no. 89, maio/2008, p. 58-59.

PAGDEN, Anthony. La ilustración y sus enemigos: dos ensayos sobre los orígenes de la modernidad. Barcelona: Ediciones Península, 2002. PAIM, Antonio. A filosofia da Escola de Recife. São Paulo: Editora Convivio, 1981.

PAYNE, Michael (comp.). Dicionário de Teoria Crítica y estúdios culturales. Buenos Aires: Paidós, 2002.

PARAíSO, Rostand. A esquina do Lafayette e outros tempos do Recife. Recife: Ed. do Autor, 2001.

Charme e magia dos antigos hotéis e pensões recifenses. Recife: Bagaço, 2004, 2a. ed.

QUEIROZ, Eça. Obras de Eça de Queiroz. Porto: Lello \& Irmãos Editores, ..., vol. I.

ROUANET, Sergio Paulo. "Do pós-moderno ao neo-moderno". In: Revista Tempo Brasileiro Rio de Janeiro: Tempo Brasileiro, v. 1, no. 1, 1962, p. 86-97.

A razão nômade. Rio de Janeiro: Editora UFRJ, 1993.

SANTIAGO, Silvano. "A palavra certa no lugar certo." In: Idéias Rio de Janeiro: Jornal do Brasil, 12.02.05, p. 3.

SENNA, Ernesto. 0 velho comércio do Rio de Janeiro. Rio de Janeiro: G. Ermakoff Casa Editorial, 2006.

TELERJ. Alô Rio: Álbum Telerj. Rio de Janeiro: Bloch Ed., 1994.

VIANNA, Wanderley Theodorico. Administrador - uma profissão bem sucedida. Síntese histórica. Rio de Janeiro: CRA-RJ, 2006.

WEBER, Max. A ética protestante e o espírito do capitalismo. São Paulo: Martin Claret, 2001.

WELLMER, Albrecht. "La dialéctica de modernidad y posmodernidad". In: In: CASULLO, Nicolas (Comp.) El debate modernidad /posmodernidad. Buenos Aires: El Cielo Por Asalto, 1995, 5a. ed. 